【目的】C型惯性肝炎に対するインターフェロン (IFN)治瘦によ D、HCV-RNAの消失とALT の正常化が認められた著効例 (CR)では組織学的にも改善することが明らかとなっているが、 有効例(PR)や再然例 (TR) での組織学的変化については未だ一定 の見解が得られていない。そこで今回我々は、IFN前後の肝組械 所見の推移を治新効果別に比較检矿した。

【方法】对象は 1987年より当院で IFN治㙩を行ったC型惯性肝 炎400例中、IFN投与前後て肝生検を施行し得た50例(男34例。 女16例、平均年数 47 才、IFN平均総投与量 $223 \mathrm{MU})$ である。こ れらを著勃例 (CR)、有効例 $(P R) 、$ 再然例(TR)、無効例(NR)の4 群に分類し各群の平組織所見の変化を HAIスコアの総スコアと 線䊒化スコア(I)て梌討した。

【結果】 (1)CR例 $(\mathrm{N}=8)$ てはHAI スコアの改善を $88 \% て 、$ 線維化 の改善を $63 \%$ て認め、悪化した症钢はなかった。(2) PR例 $(N=7)$ ではHAIスコアの改善を $57 \%$ て線䧴化の改善を $29 \%$ て梕め、 線維化の進行は1例のみであった。(3TR例(N=27)ではHAIスコ アの改善を37\%で、線維化の改善を19\%で認めた。さらに改善、 不変例をあわせるとHAIスコアて52\%、綜椎化で85\%であった。

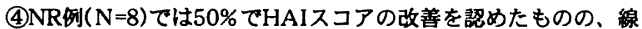
䊒化の改善した症例はなかった。

[結論] IFN治痛により、CR例以外て もHAIスコアの改善が証 められ、組織学的にもIFNの有効性が示喓された。また、楾維化 についてもPR例，TR例において改善を認めた症例为確認された。 索引用語 1.IFN治寮勃果 2 .組織学的改善度

福田吉秀

(目的) C 型惨性肝炎に対するインターフェロン（ＩF N) 治潦の 短期的評価はほほ確立されている。今回、治㙩終了後長期間释過を 観察し得た症例における I F N 治療の評価を肝機能検査の面から検 討した。

【対象】I F N投与終了後 2 年以上、経過を観察し得た悛性肝炎 15

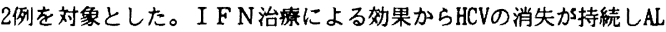
T値も持続正常であった C R 群 (44例)、HCV-RNAは消失しなかった か SALTが 2 倍程度の比較的低値で推移したPR R 群 (26例)、HCV-RNA か陽性でALTも高値、変動を示したNR群（82例）の33群に分けて検 討した。平均観祭期間は $39.0 \pm 11.4$ ケ月であり、3 群間に有意差は 無かった。

【結果】3群間に I F N投与前の線維化に差はみられなかったが、 F3症例5例中の 4 例がN R 群であり、そのうち2症例に観察期間中に肝 紐胞釈の発症か確認された。発癌症例は他にはなかった。線維化の マーカーであるヒアルロン酸值も、投与前 3 群間に有意な差はみら れなかったか、投与後 CR 群ては有意に低下し、NR群で增加の 煩向を示した。投与後に肝生検を行つた 35 例について検討すると、 I F N 投与前の線維化の程度は 3 群間に差はみられなかったか、投 与後ではCR R 群では線維化の程度がNR群に比して有意に軽減して おり、ヒアルロン酸值の結果と一致していた。血小板数については、 投与前 3 群間に差はみられなかったか、NR群では投与後低下して おり、経過艘祭中に10万以下となった5例はいつれもNR群であった。 【結語】I F N著効例は時間とともに肝機能検査が改善するのに対 し、I F N 無効でALT異常を示す例たは病態は進行していた。 索引用語 インターフェロン治燎、長期経過

P 147 に阙する給时 俉州大学医学部第 2 内科

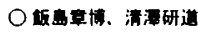

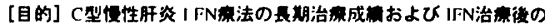

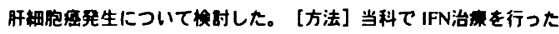

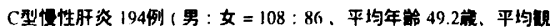

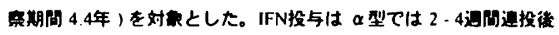

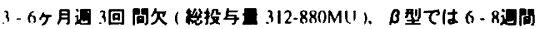

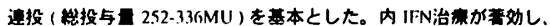

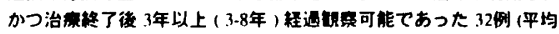

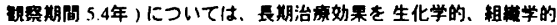

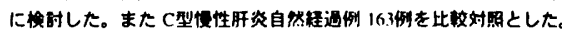

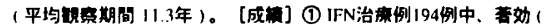

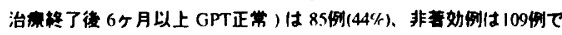

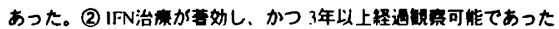
32例中 28例(88\%)では HCV-RNA持䌇哣性、4例では脽性でった。

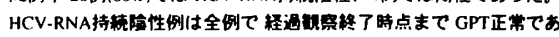

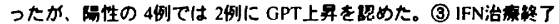

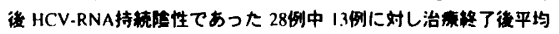
17ヶ月で施行した訮生梌では，12(例(92\%)て Activityの低下を、36

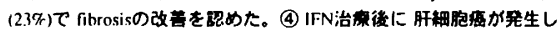
たのは194例中 11 例(1.4\%/年/人)て、自然経迥例 16.3湖ての肝梱 胞癌発生例 43 例(2.6\%/年/人)に比し有意に低年ておった(p<0.05)。

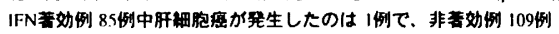

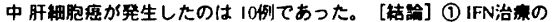

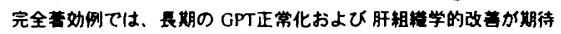

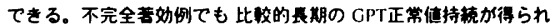
る症例も存在したが、最䅂的には肝炎が再然してくることが予测さ

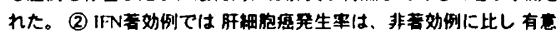

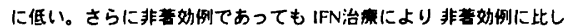

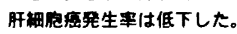

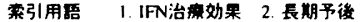

$P 148$ C 型慢性肝炎、肝硬変のインターフェロン治療後におけ 万訮細胞癌の発症について

市立池田病院内科 1 , 大手前病院内科 2 , 市立吹田市民病院 3 , 市立豊中病 院内科4, 市立川西病院 5 , 市立泉佐野病院 6 , 市立泉大津病院 7 , 大阪府立成 人病センタ-研究所第 10 部8, 大阪大学第 2 内科 9

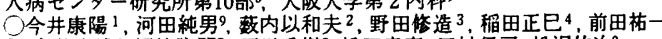
5 , 白井康博6, 福崎隆明7, 石川秀樹8, 松田幸彦, 田村倌司, 松沢佑次 ${ }^{9}$

【目的】C型慢性肝炎 (CH) 肝硬変 (LC) のIFN治療後における肝細胞艇 (HCC)の発症について, IFN治療効果およひ背景因子より検討した。

【対象および方法】1992年2月1日より1993年12月31日までに, 大阪大学 第 2 内科および成連病院にてIFN治療を開始し、治療を完了したCH, LC(Child A)患者436例をIFN治療終了C 型肝炎患者cohortとして設定した。 次に，HCCの追跡調查を行い登病例以用しては画侎猃断にてHCCを確 認した時点をend point とした。非発程例は，1995年11月1日以降に画像喰 断にてHCCの存在しないことを把握できているものを解析对象とした。 IFN治療効果は, ALT, ASTにて判定し, 著効群(CR)、短期有効群(FN治療 中のみALT, AST正常化, PR), 無効群(NR)に分類した。組峨の载維化score は新犬山分類(CHをF0-3, LCをF4)を、炎症scoreはHAI scoreのfibrosis score を除く component $1+2+3$ を用いた。

【結果】IFN治療終了C 型肝炎患者cohort436例中367例(84\%)が解析対象 となった。367例中, CHが333例, LCが34例で, 平均钼察期間は35週間で あった。HCC発症は、CH群ではCR 0/124, PR 5/100, NR 8/109, LC群では CR 0/10, PR 1/7, NR 5/17 であった。3 年後累䆏発痁本(Kaplan-Meier)は, CH群ではCR 0\%, PR 5.3\%, NR 6.9\%(Log-rank CR vs PR vs NR, P<0.05), 全例(CH群 + LC群)ではCR 0\%，PR 5.9\%, NR 10.1\%(P<0.001)であった。 発癞例でHCV genotypeを测定し得た 16 例では, 1b 14例, 2a 1例, 2b 1例で あった。発癌例と非発虎例の背景因子は，CH群において組織阵維化

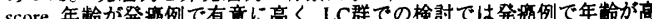
く、血小板, Albが有意に低かった。次に, IFN治療効果, 年龄, 性別, 飲酒 く.血小板, Albが有意に低かった。組織織維化score, 炎症score, ALT, AFP, Alb, 血小板, 輸血歴を变数と

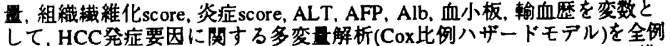
(CH群＋LC群)を用いて行った。その結果, IFN治療効果と共に組䋘线維 化scoreが, IFN治㾣後のHCC発症に奇与する有意な因子であった。

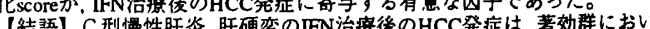
【、短部有奻群および無奻群と比し有意に抑制され, 初期 C 型肝硬変にも IFN治癔適応があると考えられた。また、組織学的stagingも、IFN治潦奻果 と共に、C型肝炎のIFN治療後におけるHCC発症を規定方る重要な因子で あった。

索引用語

1. インターフェロン

2. 肝細胞蛅 
P 149 C 型肝炎の IFN 治㭺例における長期予後の検討 秋田大学第一内科 ${ }^{19}$, 秋田労災病院消化器科 ${ }^{2)}$, 由利組合病院消化器科 ${ }^{31}$ 仙北組合病院内科 "), 公立横手病院内科 7 , 市立秋田総合病院第二内科 ${ }^{61}$ ○石井透, 小松坛史, 小野䍑, 後藤隆, 星野孝男, 藤井公生, 中根邦夫,

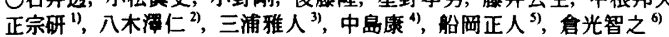

【目的】C型肝炎における IFN 治療後の長期予後を transaminase, HCVRNA, 肝組織像, 肝細胞癌の発生の面から検討した。

【対象と方法】 IFN 治察終了後 2 年以上経過短察できた 214 例(男性 126 例，女性 88 例，年令 $50.6 \pm 12.1$ 瓷，平均周察期間 3 年 2 力月)を対象と した. 治療勃果は IFN 終了後持繶的に HCV-RNAが陰性化している症 洌を著効，IFN 終了後 HCV-RNA 陽性であるがALT の正常化を維持し ている症例を有効，それ以外を無効と判定した. Genotypeは159例で 検出し，1b: 66.7\%(106 例)，2a: $25.2 \%$ (40 例)，2b: 6.9\% (11例)であった

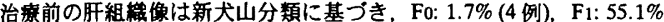
(118 例), F2: 23.8\% (51 例), F3: 11.2\% (24 例), F4: 7.9\% (17 例), A1: $27.1 \%$ (58 例)，A2: $70.6 \%$ (151 例)，A3: $2.3 \%$ (5 例)であった. 34 例は IFN治療前後で肝生検を施行した。

(成紷) 治效果は著効 $37.4 \%$ (80 例), 有効 7.0\% (15 例), 無効 $55.6 \%$ (119例)であった. Staging では, Fo は著効 75\% (3/4), 有効 25\% (1/4), 無効 $0 \%, F 1$ は著効 $41.5 \%(49 / 118)$ ，有効 6.8\% (8/118)，無効 $51.7 \%$ (61/118), F2 は著効 $41.8 \%(21 / 51)$, 有効 $9.8 \%(5 / 51)$ 無効 47.6\% (24/51), F3 は著効 $16.6 \%(4 / 24)$ 有効 $8.3 \%(2 / 24)$ 無効 $75 \%$ (18/24)，F4 は著効 $11.8 \%(2 / 17)$ ，有効 $0 \%$ ，無効 $88.2 \%(15 / 17$ であった. Activity と治疾効 果には関連はなかった. genotype-1b 例は staging の進行に従い著効率が F0: $66.7 \%(2 / 3), F 1: 27.3 \%(15 / 55), \quad F 2: 21.7 \%(5 / 23), \quad F 3: 6.3 \%(1 / 16)$ F4: 0\% (0/9) と低下した. 2a例はF0: $100 \%(1 / 1), F 1: 63 \%(17 / 27)$, F2: 66.7\%(6/9), F3: $50 \%(1 / 2), F 4: 100 \%$ (1/1)で差はなかった. IFN 治療後 の組織像で Staging の改善は著効例で $41.2 \%(7 / 17)$ 有効 $16.7 \%(1 / 6)$ 無効 $0 \%$ (0/11), activity の改善は著効例で $82.4 \%(14 / 17)$, 有効 $16.7 \%$ (1/6)，無効 9.1\% (1/11)であった. 肝細胞癌は 5 例 $(2.3 \%)$ に発生し，平 均年㰅 63 嵅，全例男性で genotype-1b の IFN 無効例であった。

【結諭】 IFN 長期著効例と有効例には肝細胞癌の発生はなく，さらに著 效例では肝組織像の改善も得られる. 一方, 無効例に対しては肝細胞 癌の発生に対して兴重な経過锶察が必要である。

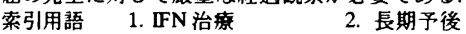

P 150 C 型慢性肝炎におけるインターフェロン治療の長期予後一未

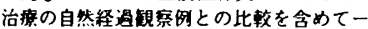

旭川医科大学第 3 内科"，札晥社会保険棇合病院"

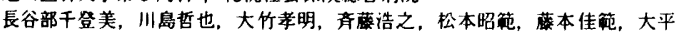
基之，小野 惒”，関谷千叠”，高後 唂"

【目的】インターフェロン(IFN)治療がC 型慢性肝炎の進展に及はす影要を明 らかにすることを目的とした。

【対象】当科および関連病院でIFN治痖を施行し、释了後2年以上程過したC

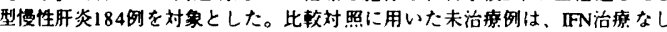
に2 6年経䢔観察され、前後で肝生検を施行して進展の有無を確認された78 症例である。

【万法】 IFN治療动果は、初回の治掩释了後6か月の時点で判定L、CR(RNA

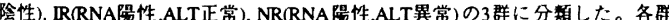
における肝硬変(LC)への進展例・HCC発症四の頻度、および進展や発整に奇 与する因子について重回淿分析を用いて検討した。

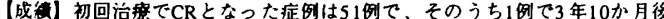

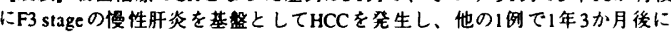
RNAの再屈性化をきたした。残る49例はRNA䧔性・ALT正常のまま経通し、 LCへの進展例はな⿰力口た。初回治接でRの症例は41外で、そのうち1例で6年 2か月捘にF3 stageの慺性肝炎を基盤としてHCCを発生し、13刚では1ー4年後 にALT值の上昇をきたしたが、LCに進展した症列はなかった。IRで再治摬を

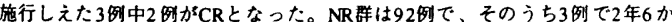
月ー6年後に肝硬変を基䑰としたHCC発生をみ、15例では肝硬変への進展が 詔められた。しかLNR群の中でも12国でALT值の6か月以上持㿠した正常化 をみ、そのうち3例ではRNAの自然陰性化をみた。NR群と末治療経過覞祭辟

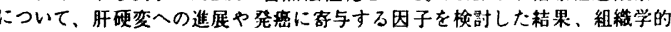

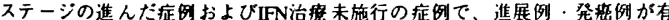
意に多加た。初診時にステージF3であった症挒に限って淮展に刹与す万因 子を㛟部した結果も、未治撩群に進展挒が有意に多かった。

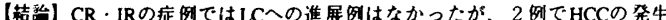

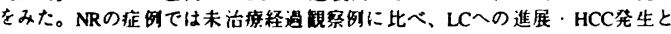
も有意心少なく、IFN治療がC型慢性肝宛患の進展を连らせる可能性があるも のと考えられた。

索引用铝 1. C 型慢性肝炎 2. インターフェロン治療

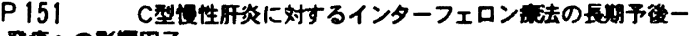

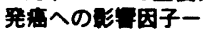

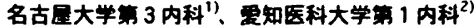

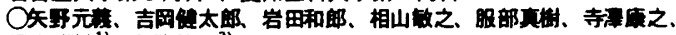

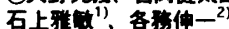

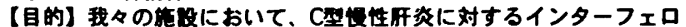

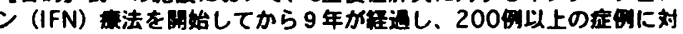

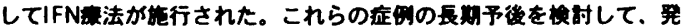

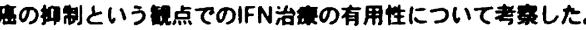

【方法】1987年6月より1994年4月までに。名古单大神第3内科及

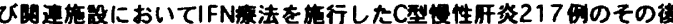

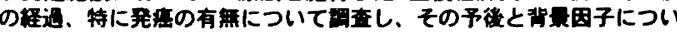

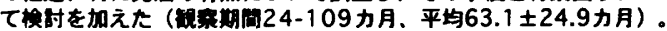

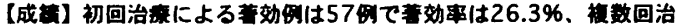

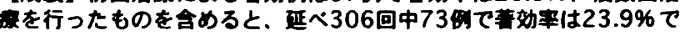

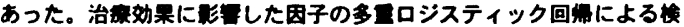
村では、genotype、性别、血暦の有無が有祀に睡していた。IFN

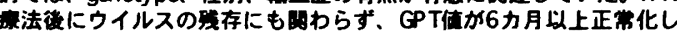

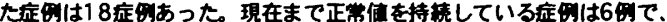

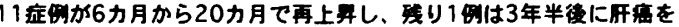

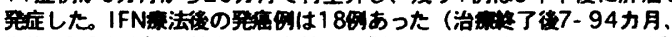
平均40.2力月）。性别では女性は2 2 のみあった。 genotypeは2a

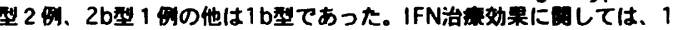

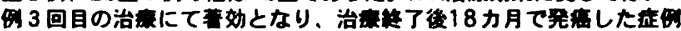

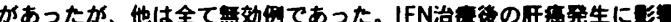
する因子について检时したところ、被数の因子を同時に检时したCox

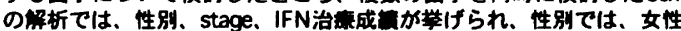

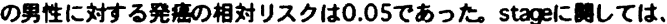
stageが 1 上留する每に発密の相対リスクは3.62 上算した。また。

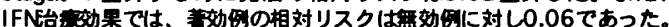

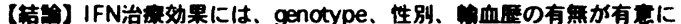

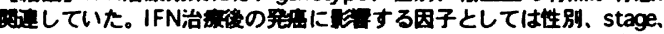

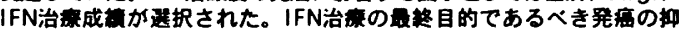
制については更に長期の梌的が必要と考えられる。

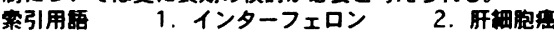

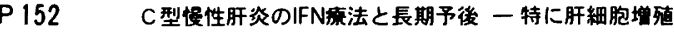
動態と発症症例について一

自分爀中央病院内科

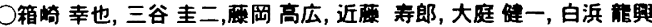

【目的】今回我々は、高・中・低用国のインターフェロン(IFN) 富法 を行い、「HCV-RNA・ALTが持統陰性」例を完全著効(CR)、「 HCV-RNAか虂性であるか、IFN治痖声後に一週性の上昇後の長期ALT の正常化」例を不完全著効(ICR)、残症例を無効例(NR) と定费し、

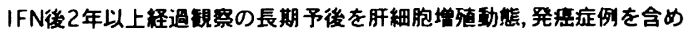
検討した。【対象・方法】対象例はC型懪性肝炎患者118例て、rIFN $\alpha$ - 2bを3MU,6MU, 10MU/回を週3回・24週間投与を行った。IFN 投与中に $6 \mathrm{MU}$ U群 1 例, $10 \mathrm{MU}$ U群3 例て、帮状管で投与中止となり、 11 症例 [3MU群: 27 例, 6MU群: 60例, $10 \mathrm{MU}$ U群: 27 例] て検讨を 行った。治㫫前の肝細胞增殖钦態は、肝生検材料一部を抗 $\mathrm{BrdU}$ 染色 を行いS期陽性細胞を、さらに一部を純エタノール固定後 抗PCNA抗 体にて、G1〜S期陽性細胞を検出した。【成綞】［1］IFN投与前の 背景因子 [ALT,ウイルス型, Staging, Acti vity, BrdU,PCNA等] に、各群間に差はなかった。[2] IFN投与終了後24ヶ月時では、 $3 M U$ 群 $=23 \%$, ICR $12 \%$, NR $65 \%, 6 M$ U 群=CR $38 \%$, ICR $12 \%, N R$ $50 \%, 10 M U$ 群=CR 37\%,ICR $11 \%$, NR 52\%であった。CRは、有意

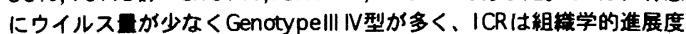
が柽であった。IFN中止例を含めると、6MU群で最も有効 (CR,ICR) 害が高值であった。[3] 発癌症例は全例NRで、3MU群 2 例,6MU群 3例,10MU群 1例て、、発見までの期間は平均38ヶ月で あった。瘦症例は、Genotype II 型が多くStaging, Br dU,PCNAが高值 の傾向であった。【結諭】1.IFN中止例を含めると、中等国(6MU) 群で最も有効率が高かった。2.BrdU,PCNAは、ウイルス型と共に 長期予後推定因子と考えられ、鍺発症例ではStagingと共に高值を示 した。

索引用語 $\quad$ 1. C 型慢性胿资 $\quad 2$. 長期予後 


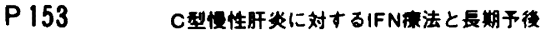 \\ 相网大学・第一内科}

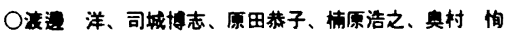

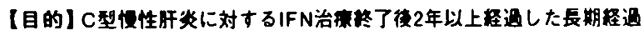

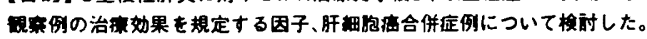

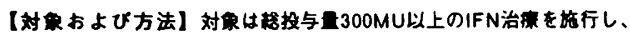

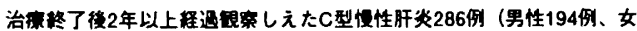

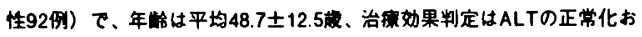

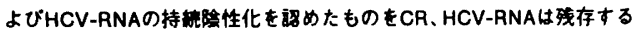
が1年以上ALTの正常化が持摬するものをPR、それ以外をNRとした。

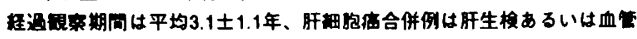

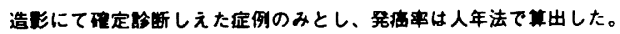

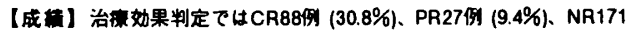
例 生体湖因子として年迹 $(P=0.0073)$ 、血小板数 $(P=0.0037)$ 、ウイルス侧 因子としてHCV-RNA $(P<0.0001)$. genotype $(P<0.0001)$ でった。

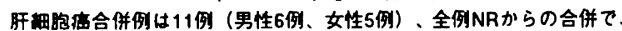

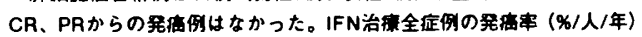

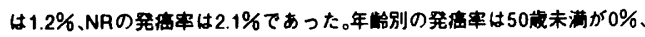

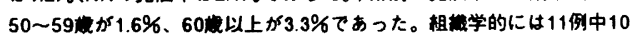

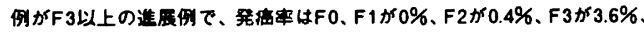

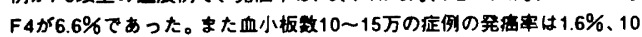

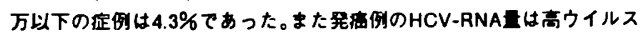
(7.1士1.1 log coples/ml) で、全例 genotype 1bであった。

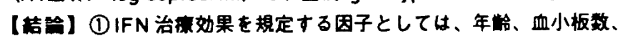
HCV-RNA \& genotype であった。

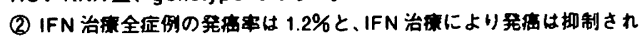

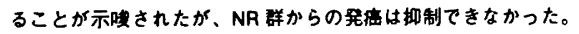

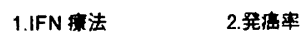

\section{P 154} についての桹时

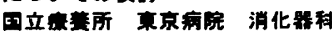

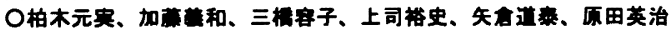

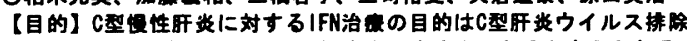

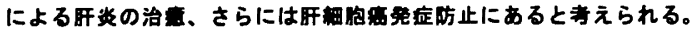

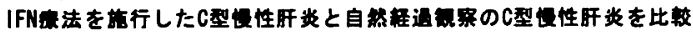

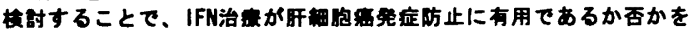

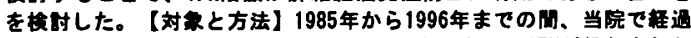

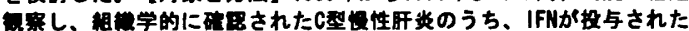

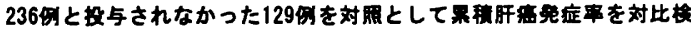
㣙した。IFNの数投与が $\alpha$ 型では4001U以上、 $\beta$ 型では250NU以上の もののみを対象とした。また両蛘の非量因子は有意差はなかった。

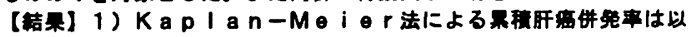
下に示す漛に」 F N 投与群で低率であった。

$\begin{array}{lllr} & 1 \text { 年 } & 3 \text { 年 } & 6 \text { 年 } \\ \text { I F N 投与群 } & 0.9 & 1.9 & 3.4(\%) \\ \text { I F N 非与群 } & 0.9 & 4.6 & 19.5(\%)\end{array}$

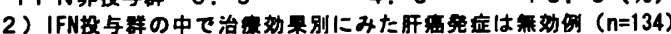

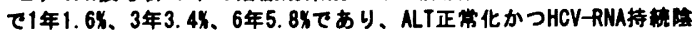

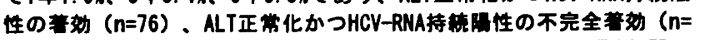
13）、ALT正常值の2倍以下へ低下の者奻 $(n=13)$ からは最畏6年间の

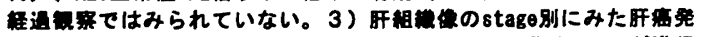
应 (人/年) \%の湌期ではIFN非投与群ではF1，F2，F3とstagoが造行

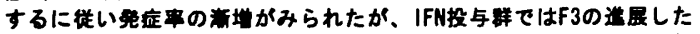
ものからみられた。F3のみの比でもIFN投与群では非投与群と比就 して以下のように勫1/41に抑えられていた。

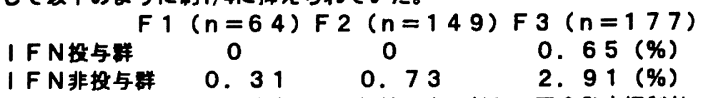

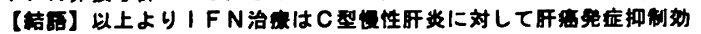
罢があると寻えられた。

索引用語 1.インターフェロン 2. 肝細胞癌

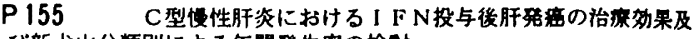
び新犬山分類別による年閒発生率の検对

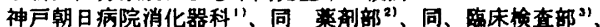

みどり病院内科"、みとり病院 梌查部31

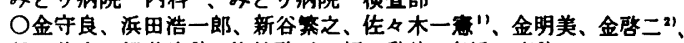
谷口美幸、梁茂完 ${ }^{31}$ 、佐伯啓三、類田照”、高棈

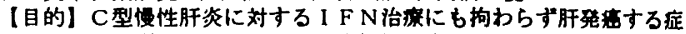
例が少なからず見られている。C型慢性肝炎の年間発症率は約 $3 \%$ と いわれているが、I FNの治療効果と年間発疝率との関保の解析は少 ない。又、I 「 N 治療前の肝組樴病変について線椎化の程度加肝発舟 に関倸するかどうかは、IF N治境後の follow upにおいて重要であ る。今回、C型慢性肝炎に対してのＩF N投与後の肝発悹の年間発生 率を治源効果別と新犬山分類を用いて検討した。

【対象と方法】对象は I F N投与を行い 1 年以上の経過をみたC型傮 性肝炎症例 118 例である。著効 (CR) はIFN投与釉了12 ケ月後 のHCV-RNA持続陰性で 31 例、有効（PR） は一過性䧔性で 41 例で、無勃 (NR) は持繶陽性で 46 例であった。新犬山分類では線 維化の程度に応じて $\mathrm{F}$ 。線維化なし 7 例、F、門脈城の線維性扰大 76 例、 $\mathrm{F}_{2}$ bridging fibrosis18 例、F $\mathrm{F}_{3}$ 小葉のひずみを伴う bridging fibrosis 17 例の四段階に分類した。

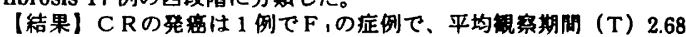

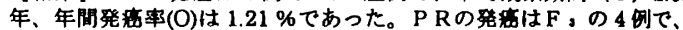
Tは 2.39 年、Oは $4.08 \%$ であった。NRの発婄は 4 例で F , 1 例、 $F_{2} 1$ 例、F 32 例で、Tは 2.45 年、Oは $3.55 \%$ であった。新犬山分 類による発席は $\mathrm{F}$ 。はなく、Tは 2.15 年、F、は、2 例でTは 2.61 年、 Oは $1.01 \% 、 F_{2}$ は 1 例で $\mathrm{T}$ は 2.44 年、Oは $2.28 \% 、 F$ 。は 6 例で Tは 2.13 年、○は $16.57 \%$ \%っった。

【結語】IF N 投与後の肝発瘻はC R 例にも見られ、CR例であって も敞重な follow upが必要と考えられた。たた、C R例はPR、NR 例に比较して I F N 治療の肝発痖抑制を示した。PR、NR例の年間

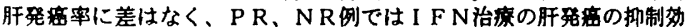

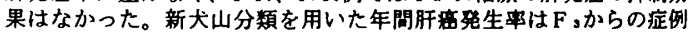
が $F_{0} 、 F_{1} 、 F_{2}$ に比して有意に高く、I F N 治挘後において線維化 を指栖とした新犬山分類による follow up の有用性が示唆された。 案引用語 1 . 肝発粚 2 . 新犬山分䅡

P 156 C型慢性肝炎に対するインターフェロン治療後の肝科胞癌の

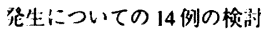

大阪府済生会中津病院朋䑏内科

○永松的介、津由泰宏、伊藤大、键田第志

目的: 我が闵の朋細胞䋨約 $80 \%$ はC 型慢性肝疾急より発生するが、C型 慢性肋炎(CHC)に対するインターフェロン(IFN)治療が開始され既に4年以 上経過しており IFN治療後の长期予後として特に肝練胞揞(HCC)の発生に ついての報告がされつつある。今回我々は当院にて経験したIFN後のHCC 発生例14症例につき FN 治療後の肝病変進展度、治療前ウイルス量、造伝 子型、治療法及び治療経過につき検討した。

方法：1992年2月より1996年3月迄に肝生検にてC型慢性肝炎と䚲断され

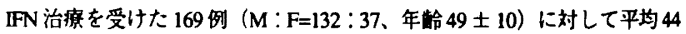
士12.9ケ月の観察をしたところ14例にHCCの発生を钼た、HCCの訩断に は、CT、MRI、USG、Angiography などの画像検査及び AFP、PIVKA-Пの 腫瘦マーカーを参考に撒診例に対しては組程学的検索を行い確定した。 絬果: IFN者効例は56例、無効例は113例でありそのうちの 14例(M:F=12: 2)よりHCCの発生をを見た。内訳は50藏より66墄 (平均58藏で組織学的に は $A C / F I=1$ 例、 $A C / F 2=5$ 例、 $A C / F 3=8$ 例であり、HCC 発見迄は治撩開始後

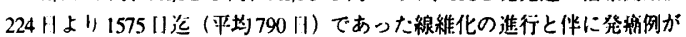

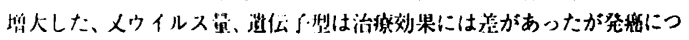
いて嘸はなかった。

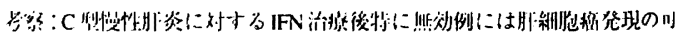

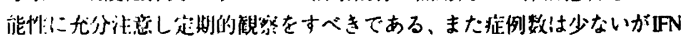

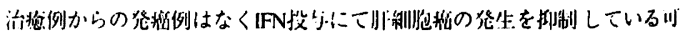

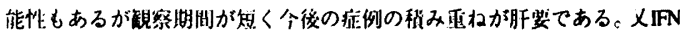

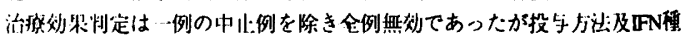

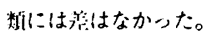

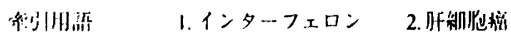


P 157

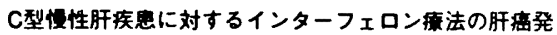
生抑制她果に墽する検討

算本大学第三内科 ${ }^{3}$ ，熊本託麻台病院 ${ }^{2}$ ，西日本病院 ${ }^{3}$ ，熊本地域医瘦 センター4

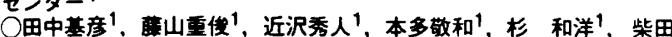

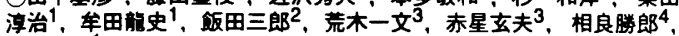
宙田公夫 1

[目的] C型恔性肝疾患ではStageの進展に伴い肝度発生事が高率と なることが報告されている。今回，インターフェロン(IFN)㩧法の長期 台看奻果の一つとして, 肝庶発生の抑制奻果についてprospectiveに 换討した。[方法］1992年1月以降当科および関連施設で肝生梌を施 行し. 少なくとも1年以上定期的にfollow-upした291例を对象とした。 IFN投与群は231例(平均観察期间3.16年)で, 治康刘果はCR; IFN投与 摞6カ月以内にALT值が持統正常化しかつHCV RNAが持続除性化 した群、PR; IFN投与終了後6力月以内にALT值が正常上限の2倍以下 に低下し持繶した、あるいはALT值は持続正常化したがHCV RNAが 持繶隆性化しなかった群，NR; そ九以外の群に分類した。肝生検を施 行したがIFN治廉を施行していない60例(平均钼察期间3.09年)を control群とした。 [成溑] control群は, CPH6例, CAH2A 15例, CAH2B 22例，LC 17例で，LCの3例(5.0\%)に肝生検後9力月，1年11 カ月、2年10カ月で肝癌が発見された。発癌率は $1.62 \% /$ 年で、LC例 では4.48\%/年であった。IFN投与群は、CPH 10例，CAH2A 99例， CAH2B 93例，LC 29例て 、 CAH2Bの6例 $(6.45 \%)$, LCの3例 $(10.3 \%)$ に肝富の発生を証め，1年以内に2例，1 2年に3例，2３年に3例， 3年以降に1例が発見された(発的军 $1.23 \% /$ 年, CPH $0 \%$ /年, CAH2A 0\%/年、CAH2B $1.99 \% /$ 年，LC $3.17 \% /$ 年)。IFN治瘄奻 果別にみると、NR83例中6例(7.23\%)，PR64例中3例(4.69\%)に肝癌 の発生を䚳めたが、CR84例中には認められなかった(発稫率CR $0 \%$ $/$ 年, PR $1.56 \% /$ 年, NR2.12\%/年)。[结論] 更に長期にわたる 経過钼察を要するが、肝瘦発生率はcontrol群に比してIFN投与群で低 い傾向にあるものの、肝癌発生抑制の見地からもIFN台康はCRを目標 とすることが直要と考えられた。

真引用語 1.インターフェロン瘦法 2.肝癌発生抑制奻果

P 158

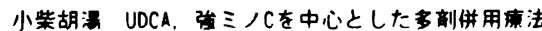

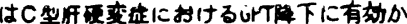

神奈川紧立がんセンター 内科第2 科

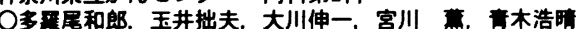

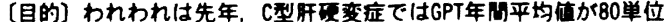

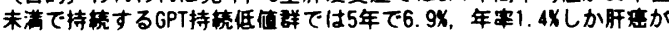
発生しないのに，GPT年平均值80単位以上が持蓅するGPT持繶高值群

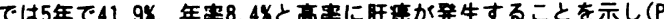
(0.005), C型肝硬变症からの肝発痘予防にはGPT年平均檤を80単位

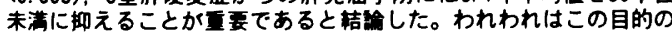
ために1989年以来，GPTを80単位末满に下げるへく，小柴胡渴 UDCA.SNMC, protoporphyrin等を使用して，1剖でGPTか880末满に下

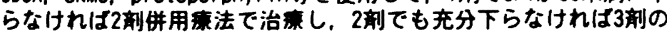
併用を出みてきた。今回は、これらの成转をまとめて、1剂 $\rightarrow 2$ 剂併 用,さらに2剖 $\rightarrow 3$ 部併用で问\%の症甽が有意にGPTが改害するかを

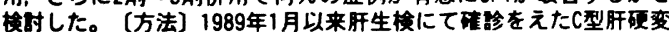
应(Chid A, B) に対し以下の抗炎症㾾法を行った。即与，小柴胡

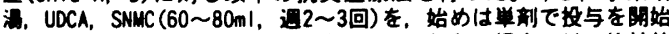

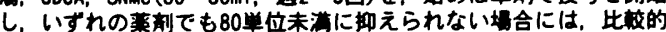

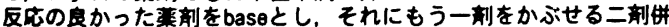

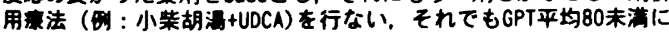
ならない堨合には3剖誁用法 (小柴胡温+UDCA+SNMC)を行なった。

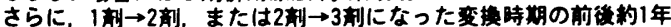

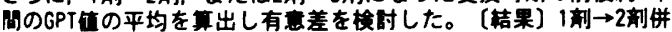

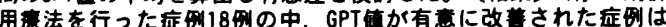

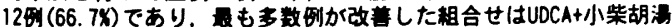
(6), 次いでSNMC+小柴胡海(4)であった。2剂併用 $\rightarrow 3$ 剂併用济法を

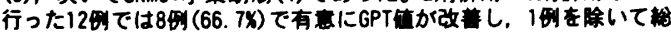

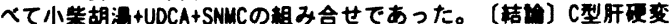

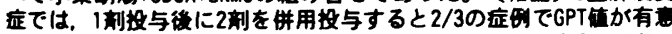
に改吾し，また，2剂投与後に3铝を併用投与すると，さらに2/3の

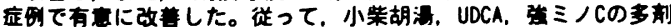

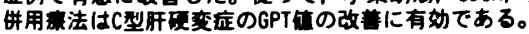
案引用铻
1. 多部併用家法
2. C型肝理変症

P 159 C 型肝炎における Aminotransferase の肝がん危険因子

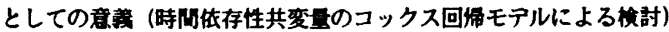
国立病院四国がんセンター内科、床研究部

○谷水正人、神野二、兵頭一之介

【目的】C 型愎性肝炎、肝硬変から肝がんの発症にいたる Aminotransferase (Trans) の意義を明かにし、さらに肝がん発症と阔遇 するTrans の推移パターンを探る.【対象と方法】対象は長期経远

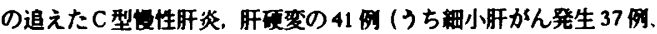

男/女：31/10，平均年制 53.6 成、筧察期间：中央值 8 年 (2 14 年)） である. エンドボイントは練小肝がん発見時とした. 湌討因子は年睮、 性別。饮酒歷, 笑煌歴, 血小板数, K-ICG, alfa-fetoprotein, Trans とした. Trans としてGOT、GPT、GOT/GPT 比の 1 年问ことの平

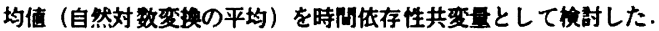
Trans 以外はすべてエントリ一時の值を入力した．校計解析は SAS6.10 (マック嫄.SAS Institute Japan) PHREG フロシジャに

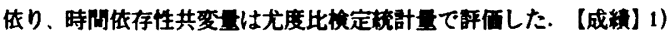

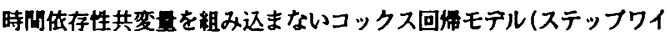
ス法)において、K-ICG、GOTの全期间の平均值、GOTのエントリ 一時の值が重要な因子として抽出された，2）K-ICG を肝の stageの 補正因子に採用L、GOT、GPT、GOT/GPT 比を時仙传存性共变量 として解析した. 肝がん発見の直前および 1 4 年前の GOT、GPT

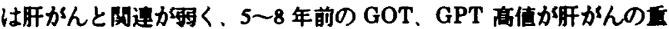
要な危険因子であった.GOT/GPT 比は肝がん吐生に重要でなかった 【結諭】Trans高值は肝がん発症の危険因子として亚要であり、特に 細小肝がんが䊽断される5〜8年前のTran8高值が重要であった。

$\begin{array}{ll}\text { 索引用語 } & \text { 2.肝がん } 2 \text { Aminotransferase }\end{array}$

P 160 C 型慢性肝疾患患者におけるウルソテォキシコー ル酸投与の影䈍

名古屋市立城西病院，"名古屋市立大学第 1 内科"1

○野尻俊埔, 川合孝, 矮仁, 小冢正雄”，佐宗克久，中

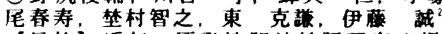

【目的】近年，原発性胆汁性肝硬変や慢性肝炎に対し，ウルソ テオキシコール酸 (UDCA)の有用性が報告がされている、今回 我々はC型慢性肝疾患患者 (慢性肝炎, 代偖性肝硬㚆) を对象に UDCA投与の有効性について検封した。

【対象および方法】血清ALT值が60IU/1以上を呈するC型慢性 肝疾患患者 80 例を対象とし、UDCA $600 \mathrm{mg}$ /日を 6 力月間投与 し、投与後 4 週間毎に訮機能検查值の変化について検㫼した。 さらに，一部の症例では，高速液体クラマトクラフィ一を用い て、UDCA投与前後の血清胆汁酸分画を測定し，検討を加えた 統計学的検定はPaired! testを用いた。

【結果】血清AST，ALT。r-GTP值は前値に比较して投与 4 週 目より有意に低下し。投与期間中は低下は持続した。UDCA 投

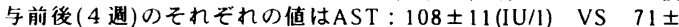
$9(\mathrm{IU} / \mathrm{l}) \quad(\mathrm{P}<0.05)$ ALT: $127 \pm 15$ (IU/1) $\mathrm{VS} \quad 75 \pm 9(\mathrm{IU} / 1)$ $(\mathrm{P}<0.001), \quad \gamma$-GTP : $84 \pm 15(\mathrm{IU} / 1)$ VS $43 \pm 8(\mathrm{IU} / 1) \quad(\mathrm{P}<0.05) \tau$ あり、改善率はそれぞれ34\%、40\%，49\%とr-GTPでより高 い改善が認められた。これに対しLDH，Alb、TP、ALP、Cho E，LAPは有意な変化はみられなかった。UDCA投与の有効例 無效例それぞれ5例について投与前と投与後の血清中胆汁酸分 画を测定し比较検的した。UDCA投与前には両群間には有意な 差はみられなかった。全例UDC A投与により総胆汁酸浱度は上 最したが、コール酸（CA），ケノデオキシコール酸（CDCA） の一次胆汁酸分画比が娍少し，UDCA分画が50\%以上を占めた 有效例は無効例に対しCA，CDCA分画の娍少が著しくより親水 性となる傾向にあった．有効例と無訤例との間でUDCAの監床 効果を予测する因子は見いだせなかった。

【結論】UDCA投与によりAST、ALT、r-GTP值は投与4 週目 より有意に低下し、投与期間中低下は持続した。酤床的に UDCAの効果を矛朗する因子は明らかにできなかったが，血清 中胆汁酸分画す検討では，瑓水性胆汁酸がUDCAに圆换される ことにより、細胞障害が防御されることが示唆された。

索引用語 1.ウルソテオキシコール酸 2.C型慢性肝疾患 
P 161 C 型僈性所炎における免疫応答とブロパゲルマニウム投与 時の細胞性免疫応答の解析

○霜出義䃥、有馬卓志、有馬媾勝1)、新上哲生2)、小原 促3)、 日野邦彦4)、奥村 康5)

1)鹿児島大学第二内科、2)鹿児島市立病院消化器科、3)OCA事雅所、 4)防街医科大学校第二内科、5)順天堂大学免疫学

〔目的〕我々は、C型慢性肝炎(CH-C)の病因としての細胞性免疫応答 を報告してきている.今回、CH-CへのプロバゲルマニウムPPGe：三 和化学研究所)投与時の細胞性免疫応答を解析し、新たな治療薬とし ての可能性を検討した。【对象・方法〕当科および関連病院にて組樴 学的に診断したCH-C患者71例(236検体)、PrGe (60mg/日,24週間)投与 CH-C10例(30検体)および正常者78例において可溶性CD8抗原(SCD8)を 测定した。PrGe被投与CH-Cにおいては経過を追って血清生化学、 SCD8、末梢血リンバ球サブセット、血清中HCV-RNA量を測定した。結

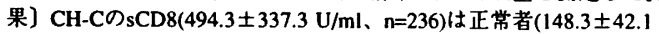
$\mathrm{U} / \mathrm{ml} 、 \mathrm{n}=78)$ に比し有意 $(\mathrm{P}<0,0001)$ に高値を示した。CH-Cにおいて sCD8とALTは有意 $(r=0,57, n=228) に$ 相関していたが、血清中HCV-RNA 量はいずれとも全く相関しなかった。PrGe被投与患者10例において $\mathrm{sCD} 8$ とCD8+/HLA-DR+T細胞の比率とは有意な相関関係 $(\mathrm{r}=0,45, \mathrm{n}=29)$ が存在し末梢血リンバ球の变動を SCD8は反映していた。PrGe投与前 に比し投与終了時、sCD8 $(\mathrm{P}<0,002) 、 \mathrm{CD} 8+/ \mathrm{HLA}-\mathrm{DR}+\mathrm{T}$ 綀胞 $(\mathrm{P}<0,03)$ 、 CD4+/HLA-DR+T 細胞 $(\mathrm{P}<0,02)$ が有意に低下したが、血清中HCVRNA量に有意な変化は見られなかった。ALTの正常化及び低下した例 においても sCD8,CD8+/HLA-DR+T 細胞,CD4+/HLA-DR+T細胞などの 細胞性免疫の活性の低下が見られた。【結論〕我々が以前より報告し ているようにCH-CにおいてはCD8+T細胞活性が元進しており、免疫 組織学的にも肝細胞破㙖にCD8+T細胞が関与し、それを反映する sCD8はALT、線維化を除くHAI score と相関している。また、PrGeは CH-C患者において血清中HCV-RNA量に関係なく綀胞障害性・抑制性 $\mathrm{T}$ 練胞、Helper/inducer T 細胞の活性を有意に低下させており、細胞性 免疫応答の調節により肝炎を鎮静化させ得る可能性がある.

索引用語 1.C型慢性肝炎 2.プロバゲルマニウム

P 162 C 型愒性肝炎肝組糡における病理所見とHLA DR およ びウィルス量との閶連についての桱討

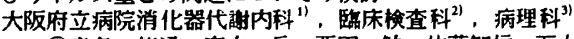

○春名 能通, 宮本 岳, 西田 觔, 佐藤智信, 石上佳孝,

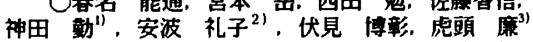

[目的] C型悛性肝炎の発症, 進展において摍主侧の免疫応答が深 く閏与していると考えられている。我々は，免疫応答を制御する因 子の1つであるHLA Class II (DRB1)と肝病理組秼所見との間連につ いて検討した. またウィルス量との関連についても検討を加えた。

[方法] 肝生换を施行したC型慢性肝炎患者92例に関し检吋した。 病理組粡変化は HAI score に, C 型慢性肝炎に特徵的である胆管障 客と脂肪要性の程度も加え倸洒した. HLA DRB1については患者末 梢単核球 DNA を用い PCR SSOP 法にて決定した. 更に患者血清 中ウィルス量は分岐鎖DNAフローブ法により测定した. [成綪] piecemeal necrosis の有無とHLA DRB1 との塔討では, piecemeal necrosis のある群において allede 1502 が有意に高頻度に珰められた

$(17.0 \%$ vs $5.3 \%, \mathrm{p}=0.03)$. 一方，胆管障害においては，これが羿め られない群において allele 1302 が著明な有意差をもって高頻度に見 られた (17.5\% vs $1.9 \%, \mathrm{p}=0.0006)$. 門脈域のリンバ球浸洞において も。リンハ球浸洞かないか堑度な群で allele 1302が有意に高乐に証 められた $(14.8 \%$ vs $3.2 \%, \mathrm{p}=0.013)$. 更に, allele 1302 を有する患者 は有さない患者に比しHCVウィルス量が有意に高仕であった (平均 $7.62 \mathrm{Meq} / \mathrm{ml}$ vs $3.20 \mathrm{Meq} / \mathrm{ml}, \mathrm{p}=0.012$ ). 以上よ り HLA DRBI allele 1502 を持つ症例は piecemeal necrosis が萡起され易く，一方, 1302 を持った症例でば脈域のリンバ球浸洞や胆管障害が苾起されにく く.ウィルス增殖は充進していることが示された。また組䓇学的所 見とウイルス量との関係では，顕著な脂肪変性を示す症例において 有意にウィルス量が少なかった (平均 $1.3 \mathrm{Meq} / \mathrm{ml}$ vs $4.4 \mathrm{Meq} / \mathrm{ml}$,

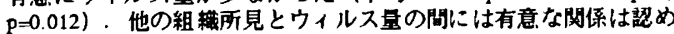
られなかった. [結語] C型喓性肝炎の発症, 進展にはHLA DR に より制御される宿主免疫応答か関与していることが示唆された。 た肝細胞脂肪変性はウィルス排除に伴う組織変化である可能性が示 された 索引用語 1. C型肝炎 2. HLA
P 163 C 型恨性肝炎におけるインターフェロン (IFW)治嫁奻果 とHLA抗原との间性について

日本医科大学第 3 内科

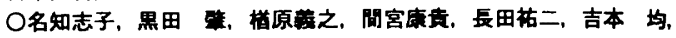

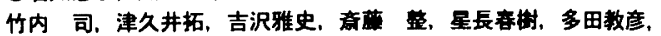
松板 金沢秀典, 小林正文

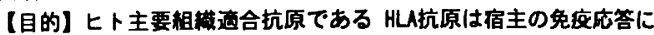
重要な役割を担っており，宿主間のHLA抗原のタイプ速いが型侵 性肝炎のIFN治暴奻果に差を生じる可能性のあることを'96 DDWJ に て報告した．今回，さらにC型侵性肝炎のIFN治瀑奻果とHLA抗原との 间連性について多変目解析を行い検討した。

【対象と方法】対象は IFN $\alpha-2 \mathrm{a}$ にて治挜を行ったC型侵性旰炎のう

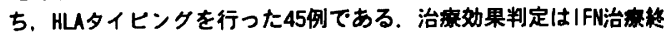
了後 1 年释迥した時点で行いALT值が正常かつHCV-RNAが隆珄化例を

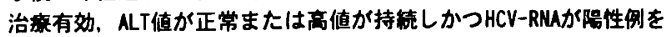

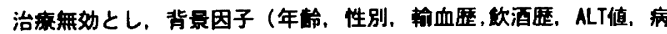

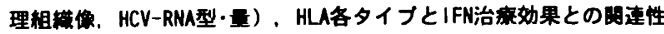
について分析した.

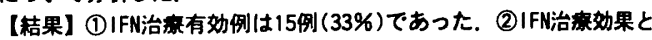
HLとの間では A11，B44，B62，DR15，DQ3の出現須度に梳計学的差がみ られ，A11，B44，B62，DQ31は治暴有効，DR15は無効例に多く認められた. (3)IFN治效効果と HCV-RNA型・量, DR15との間に有意な相関が見られ た(相関係数； $-0.58937,-0.40843,-0.32827$ ). (4)Logistic回带分析 では,IFN治獜奻果に対しHCV-RNA型·吾は強く成与しており，HLAに成 しては有意な閉連はみられなかったか，DR15,B44は影諳を及伊す可 能性が示唆された。

【結㽬】C型慢性肝炎のIFN治寮奻果に間して，宿主の因子、特にHLA タイフとと関連性を検討した. この結果,DR15が治瘄無効にB44が有 奻に閃与する可能性が示唆された.

察引用吾 1 C型侵性肝炎 2 HLAタイヒンンタ

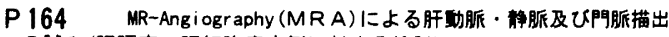
の壾み(肝硬变・肝細胞舟症例に対する梌討)

虎の門病院消化器科

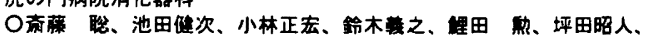

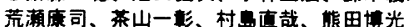

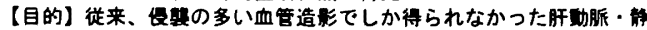

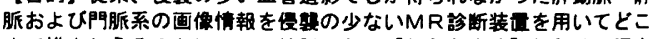
まで描出しうるのかについて梌討した。【対象と方法】対象は肝硬变

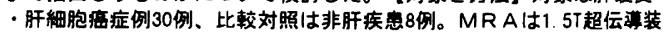
正を用い、30-Fast Spoiled GRASS法により、冠状断でTR/TE10.1/1.9 ms, FA20 FOV $32 \times 32 \mathrm{~mm}$ matri $2566 \times 160$ 、スラフ年 $72 \mathrm{~mm}$,26秒の息止め でGd-DTPA急速棦注下で縔り返し 3ないし 4 回施行し、subtractionに て别粼脈・門脈を同定した後、Maximum Intensity Projection法で作 成した。さらに、22秒の2D-Phase Contrast (PC) 法にて門脈相を梌刢し た。またDigital Subtraction Angiographyによる血管造影も施行し.

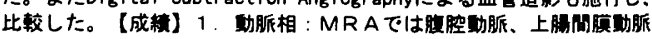

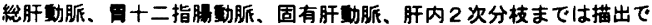

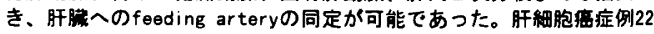
例 $(80 \mathrm{x})$ ではtumor stainも描出しえた。画像の铎明度ではやや少るも

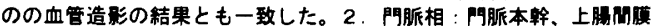

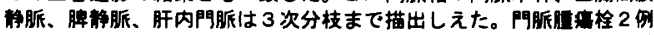
では診断可能であった。門脈圧え進のある例では左田檞脈、田・会道

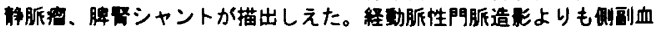
行路の描出は優れていたが、PC法にはやや劣っていた。3.角眽相： 非肝疾㭧例では3枝ともに良好に描出しえたが、肝硬变症例では2次 分枝までは描出可能なもののやや劣っていた。【結語】MRAでは 1

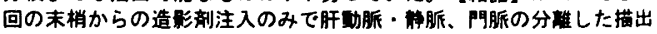

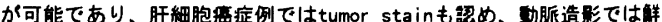
明度で血管造堁には劣るものの、門脈・解脈では血管造堁に传る情赫 を得ることが可能であり、肝硬変・肝細胞䍃症例ではfeeding artery、 tumor stain, portal invasion, 側副血行路の路断等に有用であると

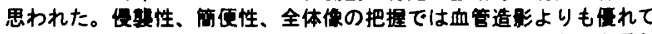
おり、今後肝硬变・肝細胞舟症倒では重要な梌㚗法となりうると思わ れた。

【索引用語】1、MR-Angiogr aphy 2. 肝細胞癌 
$P 165$ B-RT0の効果判定および経過覞繁におけるMR-Portography

の有用性。

関西医科大学第三内科" 放射繶科"

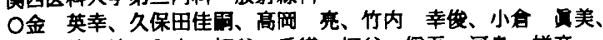

山本伸、过和之、柳谷 香織、柳谷 僧吾、河岛 祥彦、

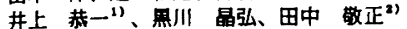

(目的) Magnetic Resonance Portography (MR-P)は、造影剂を用い

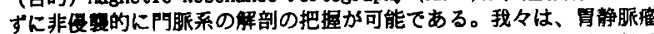
$E$ 対LBalloon-occluded retrograde transvenous obliteration(B-R

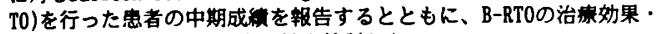
経遇覞罡におけるMR-Pの有用性を梌討した。

(患者と方法) 患者は、B-RT0を行った胃静服瘁を有する肝㖂変患者 12㙁。治腺前にMRI(T1 weighted supin echo image), MR-Pを掍像し治

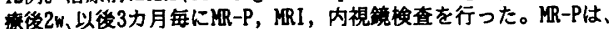

three dimentional phase-contrast 法(velocity encode $10 \mathrm{~cm} / \mathrm{sec}$ ) を使用した。

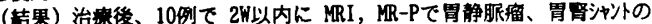
消失か既められ、内視鏡ては 3-6力月後に胃静脈瘦の消失か確認され た。残り2例で 3力月後にMRーPで消失がられ、内視䍌では 3 及び6

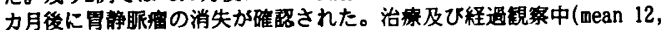

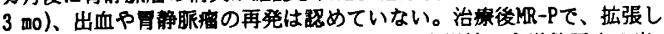
た左同静䛲が描出された2例を含む4例では、内視踥で食道静脈瘾の出 現・壇悪をみとめ内視鏡的硬化術を要した。

(結語) MR-Pての静眽瘦の消失は、内視鏡での静眽瘤消失より常に早 く㑇められ治嫁奻果の判定に有用であった。

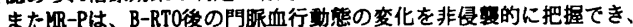
食道静脈癌增悪例の予知にも有奻である可能性が考えられた。
索引用語
1. B-RTO
2. MRI

P 166 Time Domain Color Velocity Imaging を用いた, 陚脈血流 瀷定一超音波ドブラ法との比较による検討

西神戸医療センター消化器内科

O川䗁俊彦、井谷智尚、仲濑㭲志、三村純、小萂英司

[目的] 超音波ドプラ法を用いた門䏡血流湘定は広く臨床に用いら れてきたが、いくつかの原理的な欠点があり，より簡便で正確な測 定手段の開発が待たれていた。最近開発された time domain corelation の原理を用いた color velocity imaging (CVI)は，原理的に ドブラ法よりも正碓な血流測定が可能である。今回，CVIを用いて 阴脉本幹血流を測定し、ドブラ法を用いた結果と比較梌討した。 [対象·方法] 対象は肝硬変症 11 例，愠性肝炎 7 例、肝疾患を有 しない症例 11 例の計 29 例である。使用した超音波装置はHewlett Packard GP8500 prototype である。それぞれの症例をCVIとドブラ 法を用いて叫脈血流を測定し、その結果を比較檢討した。

[結果·考察]CVI を用いて求めた門脈血流速度は $12.6 \pm 2.6 \mathrm{~cm} / \mathrm{sec}$ P脈血流量は $782 \pm 264 \mathrm{mU} / \mathrm{min}$ であり，ドブラ法より求めた門脈血 流速度は $12.3 \pm 3.9 \mathrm{~cm} / \mathrm{sec}$ 門脈血流量は $745 \pm 300 \mathrm{~m} / \mathrm{min}$ であり 比較的一致した。しかし、両者閏の变動係数は血流速度で $15.3 \%$ ， 血流甼で $25.8 \%$ とあまり良くなく、ニつの測定方法の結果が乘離す る庭例も多いことが示された。超音波ドブラ法では門脈平均流速／ 門脈最高速を 0.57 と仮定しているが、今回の検討では肝硬变症で $0.68 \pm 0.14$ 、恔性肝炎で $0.63 \pm 0.11$ 、肝疾患を有しない症例で 0.53 \pm 0.09 と疾患群で異なる上，個っの症例でのはらつきも大きく、超 音波ドブラ法に原理的な欠点があることが示された。また，CVIで は流速を測った部位で断面䅪を確实に測定できるが、ドブラ法では 流速を湖った部位と断面糟を测った部位がずれる可能性が否定でき ないことも欠点のひとつとしてあけられる。
索引用铻
1. 門脈血流量
2. 超音波ドブラ法

P 167 術前肝機能評価

名古屋大学第 2 外科

○大岛徤司,中尾昭公,金子哲也,野浪敏明,黒川㣚,高木 弘

【目的】術前肝機能評価法としてはICG testが最も一般的でる。

一方、超音波技術の進歩に伴い肝血流動熊の解析が可能となった。 肝静脈は壁が薄く血管抵抗が低いため、その波形には肝実質硬度の

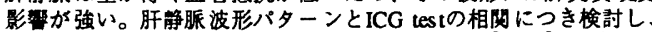
肝の組織学的所見とも対比したので報告する。【対象】'96年3月以 降に肝觧腺波形を超音波 Pul se dopplerにて解析した51例中ICG test

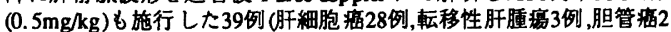

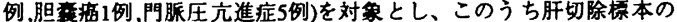
得られた18例て肝組織所見と対比した。【方法】使用機器は日立 EUB555、3.5 MHz Convex probekて右季肋下走查で中肝淨脈の血流 波形を解析。Sample pointは中肝静脈根部より4〜 $5 \mathrm{~cm}$ 末梢、Sam ple vol ume $3 \mathrm{~mm}$, PRF $650 \mathrm{~Hz} \sim 1.5 \mathrm{KHz}$ の条件て流速、流旦とResistance Index (R.I.=(最高血流速度-最低血流速度) /最高血流速度)及び Pul satility Index (P.I.=(最高血流速度-最低血流速度)/平均血流速度)を 测定。ヒーム入射角は60 度以下とした。R.I.,P.I.とICG-K值,ICG15 分停㴖事 $\left(R_{15}\right)$ との相関につきFisherのrのz変換にて検討した。肝組 織所見はH-E及び鍍銀染色にて鏡検、Knodellらのscoring systemてス コア化し検討した。【結果】R.I.は $0.76 \pm 0.21(0.29 \sim 1.00)$,P.I.は $1.17 \pm 0.45(0.35 \sim 2.10)$ であった。 R $15 \leqq 10.0 \%$ なはR.I.は0.92 \pm 0.17 、

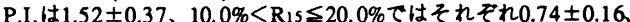

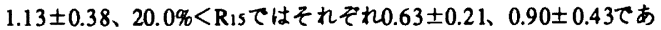
った。R.I.とICG-K值,R1s值には有意な相開 $(x=0.583, p<0.0001 ;$ $r=0.543, p<0.0005$ )がみられた。P.I.とICG-K值, R1s值には有意な相 閣 $(r=0.541, p<0.0005 ; r=0.518, p<0.001)$ がみられた。R.I.P.I. と肝租 織所見 てはperiporal necrosis( $r=0.704, p<0.001 ; r=0.717, p<0.001)$, int ralobular degenerat ion $(r=0.656, p<0.005 ; r=0.696, p<0.001)$, fibrosis( $r=0.689, p<0.005 ; r=-0.685, p<0.005)$ が有意に相䦓していた。 【結語】 Pul se dopplex 法による肝静腺波形解析は、R.I., P.I.とも ICG testと良好に相関し、肝組織所見とも相闑することより、非钼 血的な肝機能評価法として有用な手段であると考えられた。 $\begin{array}{lll}\text { 索引用語 } & \text { 1. Pulse doppler } & \text { 2. 肝機能評価 }\end{array}$

P 168 肝切除政前術中における 3 次元エコー、CTの有用性

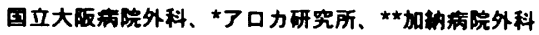

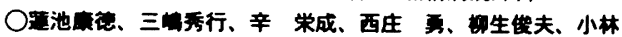

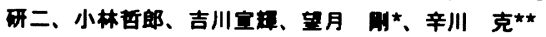

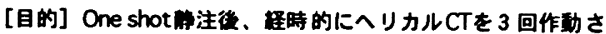

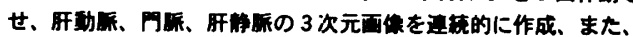

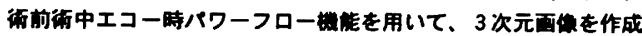

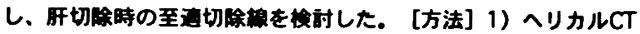
は鿓芝XピジョンGXを用い、造野(オムニパーク）を

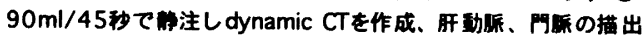
される時问の中央值を肝峌鲧相、P

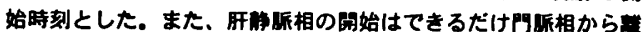

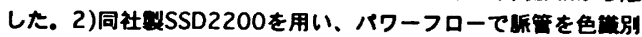
した後、三次元面得等ソフトECHO VIEWを用いて、サーフェ イスレンタリング法により三次元面能策をした。 3)同社製

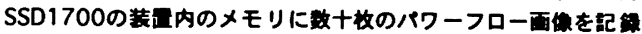
しボリュームレンタリンタアルコリスムで面做成を行った。

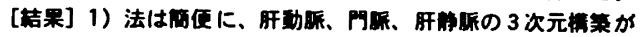

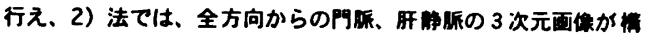
策しえた。 3）法はスキャンから画俱作成まで的 1 分て、これら

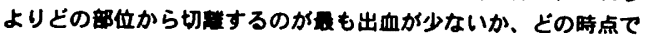

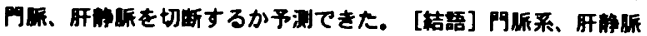

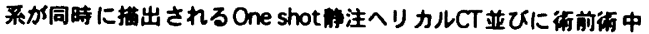

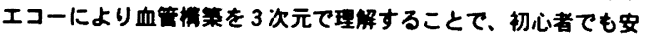
全に肝切除を施行しえる補助となった。

素引用語 1 .䏦血管 2.3 次元画像


P 169 術前3D-CTを応用した小籍畔系統的肝切除術 横浜市立大学第2外科

设会伸治、志沢艮一、金村籍秀、高橋做也、田中邦战、激本第、 透藤格、忡井秀宣、関户仁、鸩田紘

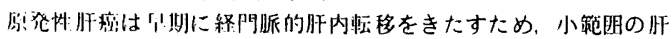
切除といえども、Glisson系脈管枝の処理を先行した系統的肝切除が

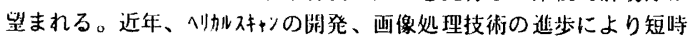
間に精密な3次元立体画像 (3D-CT) が得られるようになり，我々は これを応用した小範网の系統的肝切除を施行している。【対象と方 法】1995年2月より術前に3D-CTを施行し区域切除以下の系統的肝切 除を行った30例 (35腫湟) を対象とした。経上腸間膜動脈造影下CT (HiSpeed Advantage/RP,GE横河社)を行い門眽・肝静脈の3次元立体 画像を作製、肝内門脈亚区域枝は高安らの分類を用い检討した。本 画像をビデオテープに取り込み任意の方向に回転させ、腫㻛の占拠部位 や主要眽管との関係を検討し、さらに根治性、残肝機能などを考虑

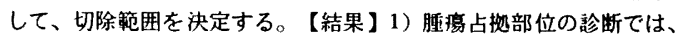
3D-CTでは小亚区域 (門脈3次分枝) まで全例部断されたのに対して、 通常のCTでは35病変中26例(74\%)であり、本法により容易に担癌グリッ 枝を同定することが可能であった。2）区域切除術以下の系統的肝切 除術を17例に行い、特に2例に小亚区域切除術が施行された。平均手 術洔問463分,平均出血量は896m!であり、術後胆汁漏（保存的に軽扶） が1例に見られた他合併症は恋められなかった。【結語】3D-CTを用 いることにより門脈了次分枝までの担瘁グ归技と漬任げレナージ静脈枝 を術前に診断でき、存在猃断に有用であった。また腫腸と主要眽管 のTWや立体閣係を容易に把握でき、师門部よりの担癌グ归枝の先 行切除を容易に行うことができた。本法は術前シュシーショッにも有用で, 特に経験の浅い術者に役立つと考えられた。

索引用竞 1. 3D-CT 2. 系統的肝切除術

P 170 99mTc-GSAシンチグラフィにおける新しい肝バラメー タについての䮡床的湌討

昭和大学藤が丘病院放射袙科

○内山勝弘、國安芳夫

アシアロ锿タンパクの血中消失量の定量的評洒は、肝特異性receptor 結合能および肝予借能を砰洒する方法として開発されたもので、 $99 \mathrm{mT}$ c標就 galactosil serum albumin(99mTc-GSA)は肝のreceptor imaging郕として、その臨床的蛣果から諸程肝疾息における倳能障害 の把握に有用であることが報告されている。現在一般に使用されてい るパラメータとしてLHL15 (肝摄取指標)、HH15（クリアランス指 䫅）、LU15（14-15分肝提取军）、1-compartment解析におけるKu およびKu/Ke、Patlak plot法におけるKuなどの検討がなされている が、これらはいすれも心㧤の関心領域の大きさに依存するもので再現 性や客钼性に問题があった。このため、われわれは新しい肝蟣能評価 のバラメータとしてL/B ratio (全肝摄取㥶) およびliver volume index (肝容䅡指摽) を考原した。【目的】本研究の目的は、これら 新しいバラメータによる肝橙能検查法の臨床的有用性についての評 価、ならびにL/B ratioとLVIの正常值を決定することである。【対象 および方法】対象群10例、肝疾患症例145例（肝硬变あるいは恔性肝 炎合併原発性肝瘦88例、肝硬变24例、僈性肝炎19例、急性肝炎 10 例、应肝炎4例) の計155例を対象とした。99mTc-GSA肝シンチグ ラフィで得られた新しいバラメータ值と従来の肝バラメータ值および

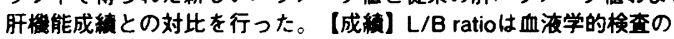
Alb $(r=0.54)$, PT(0.54)、HPT(0.71)、LCAT(0.59)、ICGR15(0.69), KICG(0.71)と良好な相関を示し、従来のGSAバラメータである HH15(0.87)、LHL15(0.86)、LU15(0.87)とも良好な相関を示した。 一方、LVIもこれらのバラメータと良好な相関があった。また、L/B ratio值は対象群では0.68士0.05であったのに対し、肝硬变群では $0.45 \pm 0.17$ と有意（p<0.0001）に低下していた。【結論】われわれ の考宩したL/B ratioならびにLVIは、99mTC-GSAによる心䏸のROI設 定に影䭗されない再現性のある客観的なパラメータであるといえる。 $\begin{array}{llll}\text { 索引用語 } & \text { 1. 99mTC-GSA肝シンチグラフィ } & \text { 2. 肝㭫能検查法 }\end{array}$
P 171 新しいコンバートメントモデルを用いだのTC-GSAシンチ グラフィーによろアシアロ楉蛋白受容体総量の测定

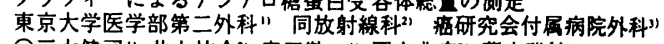

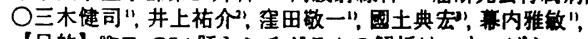

[目的] 9mTC-GSA肝シシチグラムの解析は、もっばらLHL15とHH15 にて行われているのが現状である。しかしこれらの指標では、定量的 な肝譏能絵量を推定できない。また、コンパートメントモデルを用い た受容体量の定量的な推定は、Veraや河によって試みられているが、 彼らのモデルは、現実の代期過程を正確に反映するものではない。我々 は、受容体の再循聚や、エンドサイトーシスの機檅を組み込んだより 現実に近い代謝過程を再現したモデルを考莱し、震小二采法を用いて、

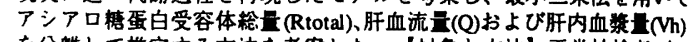
を分離して推定する方法を考案した。【对象と方法】正常被梌者5名 に镉Tc-GSA 3mg および9mgを投与し、ガンマカメラにて60分間 dynamic imageを撮像した。肝、心、肺の時間放射能曲線(TAC)を作成 し、肝のTACと心肺のTACの相対的な関係より、肝集皘GSA量時閂曲 線を計算した。7コンバートメントモデルより得られた連立倒分方程 式により計算された肝集嗥GSA量について、5名の計10回の娜定デー 夕を同時に最小二乗法による解析を行い、バラメーターを決定した。 Rtotal, $Q, V h$ Vついては、症例により可变とし、平䚘定数( (Kd)、細胞内 への取り込み速度(kin)、細胞表面に存在する受容体の割合(rs-i)、肝細 胞内の受容体の秘離速度 $(\mathrm{kr})$ は, 症例によらず不変とした。次に肝切除 術前患者 (旰硬変 32例、慢性肝炎22例、正常肝17例) に-Ta-GSA $3 \mathrm{mg}$ を投与しRtotal、Q、Vh、を推定しその有用性を検討した。【桔 果】正常被検者の解析の耛果、 $\mathrm{Kd}=0.033 \mu \mathrm{M} 、 \mathrm{kin}=0.63 / \mathrm{min} 、 \mathrm{rs}-\mathrm{i}=$ $5.7 \% 、 \mathrm{kr}=0.03 / \mathrm{min}$ となり、Aswell 5 の in vitroの実験䊅果と矛盾しな いものとなった。Rtotalは、正常肝群で $0.53 \pm 0.20 \mu$ mole, 情性訮炎群 で $0.39 \pm 0.14 \mu \mathrm{mole}$ 、肝硬変群では、 $0.26 \pm 0.13 \mu$ moleと各群間で有 意差を持って明眿に分離された。Qは、各群間に有意差を認めなかっ た。Vhは肝硬変群で正常肝群より有意に低下していた。【結論】我タ のモデルは、アシアロ䅯蛋白の代懒過程を忠実に反映したものであり、

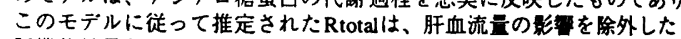
肝機能総量として、有用であると考えられた。

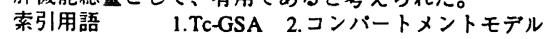

P 172

肝細胞媳に対するLp-TAE後の治廉奻果判定 一超音波バワードブラ法の铎価一

奈良県立医科大学 䏸的放射線科・放射線科

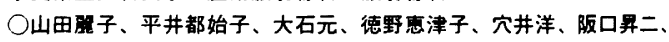
本田伸行、阪口浩、松尾尚樹、打田日出夫

【目的】肝細胞湾LP-TAE後の治療好果判定に対する超音波バワード ブラ法(PDS)の有用性を検璟する。

【対象ならびに方法】LP-TAE前・後にPDSを旅行した肝細胞袖30結

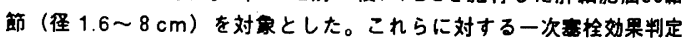
のPDSの有用性を、ほほ同時期に施行した他画像所見と対比すること により評洒した。PDSによるLP-TAE寒栓効果不充分の喰断は、PDS

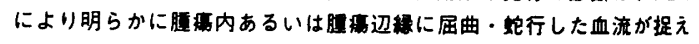
られた㛫合とした。使用超音波装置はGE・椣河 LOGIQ 700であ る。

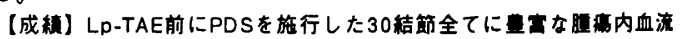
が捉えられ、これらのLP-TAE 1 週间以内のPDSで19結節に㯖的内血

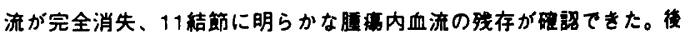

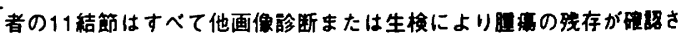
れた。Lp-TAE後、PDSで胴满内血流が捉えられなかった19結節中1

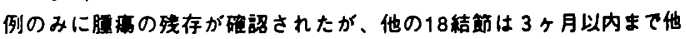

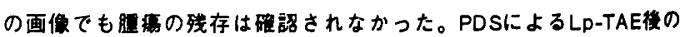
一次害栓効果判定のsensitivity は $94.7 \%$, specificityは $100 \%$ であ た。

【結諭】超音波バワードブラ法の肝細胞絽に対するLp-TAE後の一次 䨤拴奻果判定に対する有用性が示昗された。

絭引用铻：1. Power Doppler Imaging

2. 肝細盷离 
P173食道胃静脈缩における診断と治療の進歩一超音波内視鏡 (超音波細佳プローブを含む)による新たなる展闰

自治医科大学消化器内科门長嵌伸彦、木村 健

【目的】食道胃静脈痹の診断と治㙩における超音波内視鏡の臨床的有 用性は，varicealography(硬化療法時)や血管造影法などの侵蛏的アブ ローチと異なり非侵䘫的に反復施行でき,リアルタイムに、より詳細 で正磪な食道胃壁内外の血流分布を含む形態診断，さらに機能的診断 として静脈痛の血行動態を評価可能なことである。今回は、より効率 的て奻果的なEVLのために超音波内視鏡を応用したので報告する。

【対象と方法】对象は食道胃静脈㴼症例50例。治療は治療奻果(静脈 据内腔や貫通枝の閉塞や途絶など判定に超音波細径ブローブを併用 する密集多数結禁法で食道静脈乍結禁術(EVL変法)を行った。検查は 通常内視鏡およびカラードブラ超音波内視鏡: CD EUS (龟子リニア方 式)/東芝一町田製EPE. 703FL(7.5MHz)と超音波細径プロープ: UMP (メカニカルラシアル方式)/Aloka.SSD550(8Fr. 15MH2)で行った。

【成縝】(1)超音波診断上，良道静脈瘦や貫通枝にはUMPが，傍食道 則副血行路(奇静脈を含む)や胃静脈㴼および供血路にはCDEUSがより 有用であったが，两者の併用が望まれた。(2)EVL変法では，EVL原法 (Stiegmann法)に比し有意に(Kaplan-Meier法, D 00.001$)$ ，食道静脈疾の 再発(增悪を含む)までの期間が延長( $50 \%$ 再発期間: 変法; 16.0 力月，原法: 3.0か月儿，再発の程度も轻娍した。きらにEVL变法で治療後、1年以 上(平均 $21.3 \pm 3.7$ 力月) の非再発群 10 例と 1 年以内 $($ 平均 $6.5 \pm 1.4$ 力月 1 の再

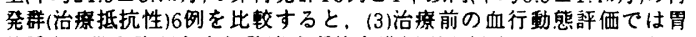
静脈痛や供血路があまり発達せず傍食道側副血行路/drainage veinとし て幾能が著明な症例ほど再発が少ないことが示惨された。(4)治療後 の血行動態評価では, 非再発群で食道胃壁内 $100 \%$, 食道壁外 $50 \%$.胃 壁外 $60 \%$ が娍少傾向を示した。再発群では食道壁内 $100 \%$ ，食道壁外 $50 \%$ が娍少傾向を示したが、胃壁内50\%，胃壁外 $83 \%$ が不変または增 加傾向を示した。両群ともEVL原法と異なり食道胃壁内外の血行動態 に種々の変化を認めた。

【結諭】食道胃静脈嘴の診断と治療(EVL変法)，さららに治療法の選択 (治療奻果の予測)や治療後の血行動態評価に超音波内視鏡は有用な modalityと考えられた。

【索引用語】食道静脈痒結慗術(密果多数結禁法)
$P 175$

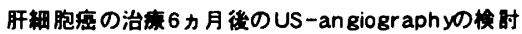
一その有用性と限界一

粗浜市立大学医学部附盾浦舟病院第二内科

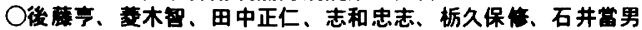

【目的】私たちは平成6年10月より肝細胞癌の路断に婘して $\mathrm{CO}_{2}$ を用いたUS-an giographyを棐入し、治腺の効果判定と経皮的工夕

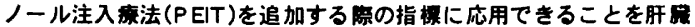
詵上に発表した(Vol.37 No.10に揭献予定)。今回さらに症例を重ね その有用性と限界について梌时した。【方法】対象は、PEIT, 肝趿

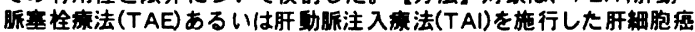
16 症例、延へ40病变である。治㾜 6 力月後にUS-angiographyを施 行しその所見を通常のUS,CT,angiographyの所見と比䖝检㣙した。

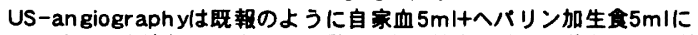
$\mathrm{CO}_{2}$ を $5 \mathrm{ml}$ l溶解したものを㟁勤眽1次分枝より注入し施行した。注

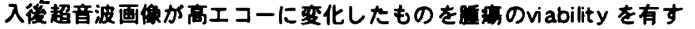
る病变と判断した。【結果】40病変のうち通常のUSで病変を描出で きたものは30病変だった。US-an giogr aphyでviabilityを现めたも

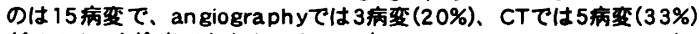
がviabilityを検出できなかった。一方US-angiographyでviabilityを 訆めなかったものも15病变で、うち1病变(6.7\%)はCT,

angiographyでviabilityを㑇めた庭例だった。その他14病変はCT, angiographyでも viabilityを訆めなかった。通常のUSで病変を珒现 できなかった10病变はすへて血管造影で梌出できたか、その中て US-angiographyで検出できたものは3病変のみだった。軨出できな かった7病变は部位的にUSで怜出できなかったものが4病变、小诘節 の多発例が病变だった。飡出できた3病变のうちでも病变は小蛣

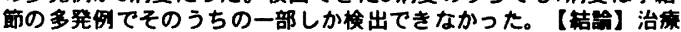
後の肝細胞癌に対するUS-an giographyは通常のUSで病変を捉えら

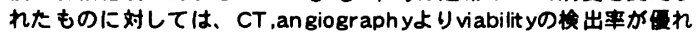
ており見逃しもこく少数であった。しかし通常のUSで捉えられない ものは評価が困勤であり、特に小結節が多発している再発は㛟出か 困難だった。

实引用語 1.US-angiographv 2.肝細胞㿋

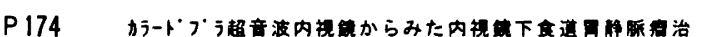

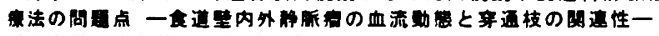
昭和大半医学部第二内科数咅

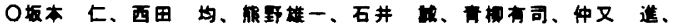
米山整一蚛、三田村圭二。

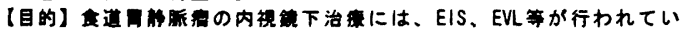

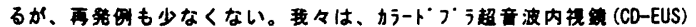

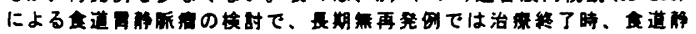

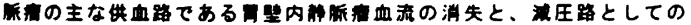

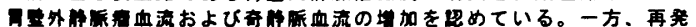

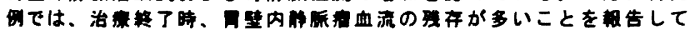

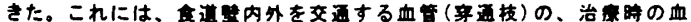

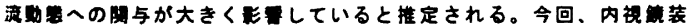

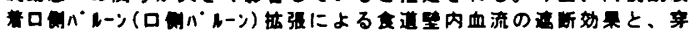

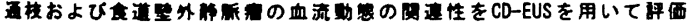

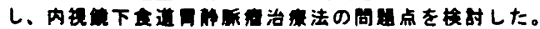

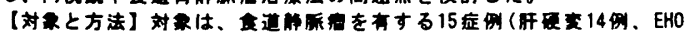

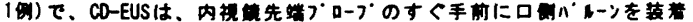

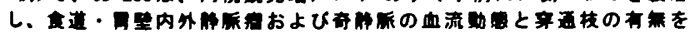

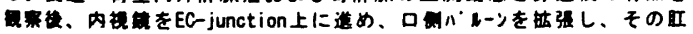

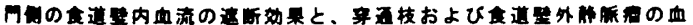

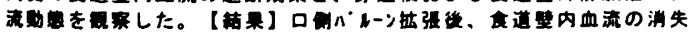

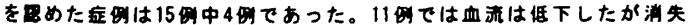

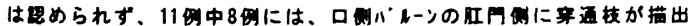

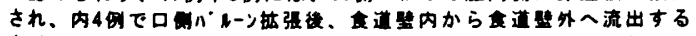

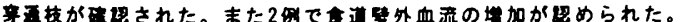

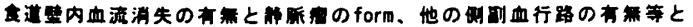

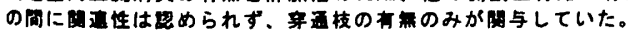

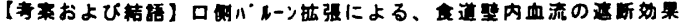
は乏しく、血流が速断されない应では、5\%ethanol amine-oleate (EO)

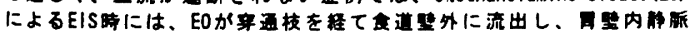

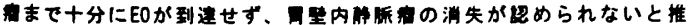

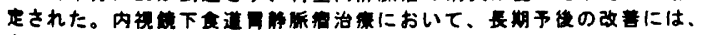

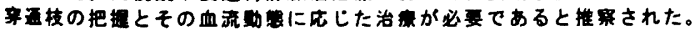

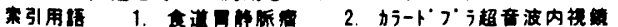

P 176 C 型肝硬変症例における肝組織中HBV-DNAの検出と 発㾂との関連

長崎大学第一内科、同 保健管理センター、

○柴田雄一、井石圭子、有馬哲彦、漥崎圭輔、鶴田正太郎、

中尾一彦、加藤有史、中田恵輔、石井伸子、、长淿重信

【目的】HBVとHCVでは肝発噋のブロセスに差異があると考えら れている。HBVはそれ自体が発癌のinitiatorとして機能し得るが、 HCVについては宿主DNAへの組み込みは見られず、発痥機序は不 明である。本邦では欧米に比較してC型慢性肝疾患からの発癌率が 高く、またHBVキャリアーが多いことから、HCVの発癌にHBVが 関与している可能性も考えられる。そこで、C型肝硬変症例の肝組 織よりHBV-DNAをPCR法により検出し、発癌との関連について検 討した。

【方法】対象は1980年から 1994年の間に当科に入院したHBs抗原除 性のHCV関連肝硬変 70例。そのうち 5 年以上経過観察し発癌して いない17例を非発痦群とし、释過中に発癌した53例を発癌群とした。 男女比は非発痹群で 7:10、発癌群で39:14、平均年龄は非発癌群59 歳、発癌群57歳、経過钼察期間は非発癌群で平均8.0年、発癌群で は平均4.6年であった。これら症例において、肝硬変診断洔のバラ フィン包埋肝生検組織より DNAを抽出後、nested PCR法をもちいて HBVの S 領域及び X 領域の検出を試みた。コントロールにはb-actin DNAを用いた。

【結果】(1) 発㿋群ては非発癌群に比へ、男性が有意に多かったが $(\mathrm{p}<005) 、$ 平均年龄では差が見られなかった。(2) HBV-S 領域は非発 癌群 17 例中9例 $(53 \%)$ 、発癌群53例中 25 例 $(47 \%)$ て検出され而群間で 差が認められなかった。HBV-X領域は非発癌群で3例(18\%)に検出さ れたのに対し、発瘦群では25例(47\%)で検出され、発癌群で検出頻 度が有意に高かった

【結論】C型肝硬変症例の肝組織ではHBV-DNAが約半数に検出さ れ、特にX領域は発痘群で検出率が有意に高く、肝癌への進展に関 与している可能性が示唆された。

索引用語 $1 . \mathrm{HCV}$ 2. HBV 
P 177 C 型肝癌症例のホルマリン固定パラフィン包埋 (FFPE) 粗藏からのHCVの梌出とNS5A領域における7ミ/酸变異の検討 日本大学第三内科"、国立予防街生研究所感染病理部"

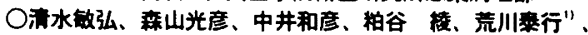
阳部是治"

[目的] C型僈珄肝炎に対してインターフェロン痤法が広く行なわれ

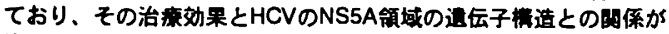
注目されている。我々は、C型訮癌庭例の福部におけるHCV-RNAの

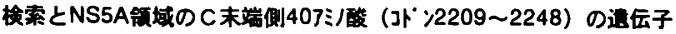

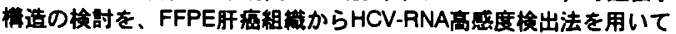
行なった。

[対象、方法] 血中HCV-RNAP珄てgenotype-1bの肝癌靑者で肝切

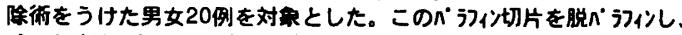

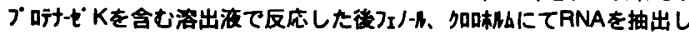
た。このRNAを錆型として5' NCとNS5A領域のブ nested RT-PCR法にて城幅した。さらに、NS5A隄性の2例について

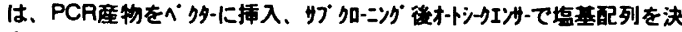
定、フミ酸に变換し比較した。

[拮果] 1) FFPEよりHCV-RNAか550\%で画接検出可能であった。

2) NS5A領域でのアミ/酸变暴はそれぞれ2〜5ヶ所にみられ、同一症例 间での差異は少なかった。3）異なる2症例の7ク口-㓌てにおいて、外

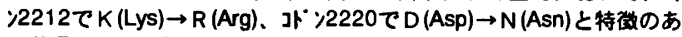
る共通したアミ酸变異がられた。

[拮論] 1) FFPEを用いた高点度検出法により、肝癌組溚からウ仍 目の少ないHCV-RNAを直接検出し、茺伝子いべでの解析への応用か

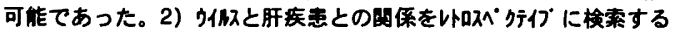
上で经めて有用な方法と考えられた。3）異なる肝癌症例间でNS5A 領域でのア酸变異に共通性がみられたことは、ク价の持繶惑染状態 と肝病との的連を考える上で示唚に晋む蛣果であると考えられた。 索引用語 1.C型肝癌、2.NS 5 A、

\section{P 178 肝発癌における組み込み型X透伝子の関与} - HCV抗体陽性201洌を含む肝切除例32例の検討

千菓大学第 2 外科

○浦島哲郎、磯野可一

【目的】血清学的検尉でHCVの肝発癌への関与が考えられてきた症 例の中にも少なからずその肝癌組織中にはHBVゲノムのクローナル な組み込みかか認められることを報告してきた。今回はその迹层子 座物がトランスの枟写活性を有するとされる、、及びpreS2/S造伝 子の組み込みとともに奋NAの発現を HBV関連のみならずHCV関連 肝癌においても検索し、とりわけ入息伝子の組み込みと肝発瘦との 関連を検討した。

【対象と方法】HCC32例一HBs抗原陽性7例、HCV抗体陽性20例、何 れも陰性5例一の新铎切除標本からDNAを抽出した。制限䤃素Hind IIIで消化後、full-length HBV DNAをプロープ用いてSouthern blottingを行い、HBs抗原陽性7例全例とHCV抗体陽性の20例中10例 とその他1例の計18例 $(18 / 32,56 \%) に H B V$ DNAのクローナルな組み込 みが検出された。これらにつきさらにメ、及びpreS2/S領城をつ

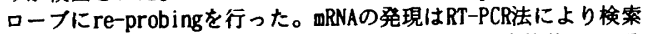
した。即ち、抽出されたRNAを逆枟写醅素でCDNAに変後、X、及

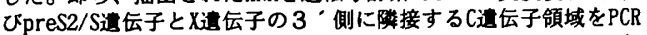
(first step)に供した。なお、HCV感染は 肝組織中のHCV RNAを2 段䧄のRT-PCR法で検出することによっても確認した。

【結果】ス、及びreS2/S領域をプローブに用いたre-probingによ り道伝子は約 $80 \%$ に れた。さらにmRNAの発現は、过伝子の発現は87.5\%と高率であっ たが、preS2/S.C这伝子は各々、43.8\%,37.5\%であり、HCV感染の有 無に関わらず X这伝子の組み込みは高頻度で、その奋NAの発現も 選択的かつ高率であった。

【考察】クローナルな組み込み型のHBV DNAがB型HCCのみならず、 従来C型HCCとされてきた症例においても高頻度に梌出されたこた は 血清学的榆封のみで肝発瘦へのウイルスの関与は論しられな いことを意味する。さらに組み込み型のHBV DNAを有する症例では 迹云子の組み込みとその発現か肝発癌に主たる関与をしている可 能性が示唆された。 索引用語： 1 , 肝発癌、 2 , HBVX造伝子
P 179 C 型慢性肝疾患における肝細胞の不規則再生の意意

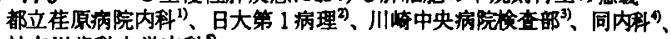
神奈川蔽科大学内科?

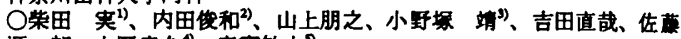
源一郎、上野幸久"、森惯微夫”

〔目的〕 C 型慢性肝疾息の肝発症における肝細胞の不规則再生 (irregular regeneration: $\mathbb{R}$ )の成与について梌討した。

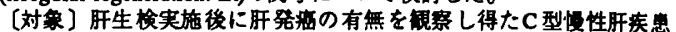
242例を対象とした。肝生梌時に肝我の合併またはその器いがある休、

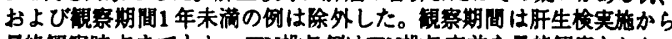
最終毁察時点までとし、IFN投与例はIFN投与直前を終锶察とした。

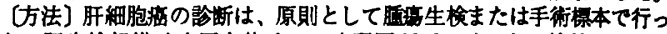
た。肢生榆組機は病歴を伏せて、病理医がフララインドで検镜した。 $\mathbb{R}$ の程度は肝細胞の Pleomorphism, Anisocytosis, Bulging, Map-like distribution, Nodularityを評価の対象として給合的に0〜5の6段降にス コア化した。

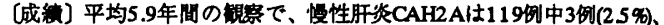

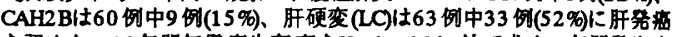

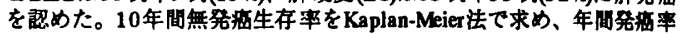
を計算したところ、CAH2Aは0.5\%、CAH2Bは2.1\%、LCは6.7\%であっ た。肝発疾例 45 例と5年以上無肝発祝例 92 例における

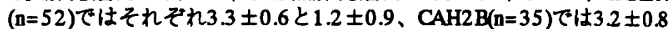

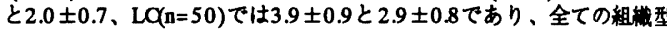
において発洌でRか有意に高值であった

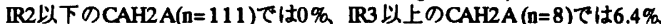
IR2以下のCAH2B $(n=43) て ゙ は 0.6 \%$ IR3 以上のCAH2B $(n=17) て ゙ は 4.9 \%$ IR3 以下のLO(n=27)では2.3\% R4 以上のLC $(n=36)$ では.7\%であり、

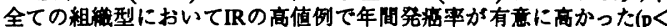
0.01: 一般化Wilcoxon模定)。

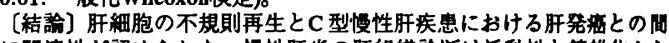

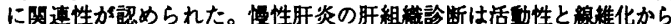
なされているか、肝発恳予知の見地からは不规則再生の程度も考虑す できである。

索引用語 1 不规則再生 2 肝細胞藻

P180 世界各国におけるC型肝炎ウイルス感染者中の

GBV-C/HGVについての検討

1 ) 名古屋市立守山市民病院内科、2) 名古屋市立大学第二内科

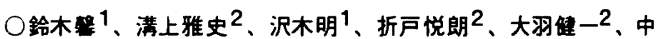

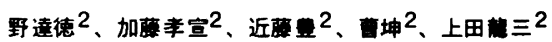

(目的) ヨーロッパ、中東などさまざまな地城のHCV息者につ いてGBV-C/HGV RNAの梌出をおこなった。更にその坦基路 を決定し分子進化学的に检討した。

（方法） 23 力国 96 例のHCV RNA淂性慢性肝疾㭧息者につい

ておこなった。すべての症例にMcComishらの方法によるRFLP 法によるHCV genotyingをおこなった。GBV-C/HGV RNAの 検出は5'-UTRの配列のprimer set 使用し、场基列列の決定も 同部位についておこなった。これらの列を使用しNeighborjoining法により分子系統橶を作成した。

（成練）GBV-C/HGVは 96 例中 8 力国、18 例(18.8\%)に唄 出された。これらのうち半数は経解脈麻菜使用者 (IVDUs) て あった。HCVの genotypeはtype 1，2，3，4，5がみられたが、 GBV-C/HGVはHCVのgenotype 1，2，3の症例に湌出された。 GBV-C/HGVの塩基列列は多样性がみられ分子系統榯上では大 きく3つの集団に分かれた。

（結諭）GBV-C/HGVは多梾な地域に分布しており、特に

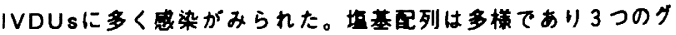
ルーブに分かれていた。索引用語 $1 . \mathrm{GBV}-\mathrm{C} / \mathrm{HGV}$ 
P181 GBV-C/HGVのgenotypeとアジア・アフリカ・オースト ラリアにおけるその分布

名古展市立大学医学部第二内科

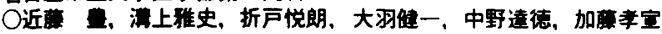
上田表三。

【目的】GBV-Cは西アフリカ由来の，HGVはアメリカ由来の息者よ り発見されたが、その後の梌即より両者は同一のウイルスで臬う genotypeの可能性が高いと考えられている．今回我々は日本を含め たアジア、アフリカ, オーストラリアにおける, GBV-C/HGVの genotypeを、分子系轨解析およびRestriction Fragment Length Polymorphism (RFLP) 法で湌討した。【方法】日本（肝疾急息者）

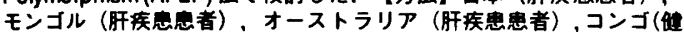
常者）それぞれ203，112，30，30梌体につきRT-PCR法を施行し GBV-C/HGV RNAの湌出を行った. GBV-C/HGV RNA淂性例のうち42

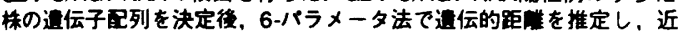

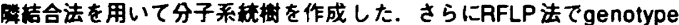
分数を行いその分布を检时した。 【结果】 日本、モンコル,オースト

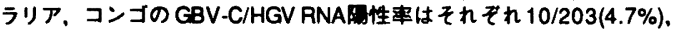
17/112(15.2\%), 9/30(30\%),6/30(20\%)であった. GBV-C/HGV RNA烈性株のうち各国それぞれ10，17，9，6株，計42株の塭基医 列による分子系䋘解析では，GBV-C/HGVは， GBV-C型、 HGV型、》 ジ型のgenotypeに分類された.このうち日本の10株はHGV型 2 株 とアジア型8 株、モンゴルの17株はHGV型 5 株とアジア型12株に、 オーストラリアの9株はすべてHGV型に，またアフリカの6株は HGV型 2 株とGBV-C型 4 株に分類された. 一方RFLP法でも，GBVC/HGVは3つのgenotypeに分類されたが、それぞれ分子系統橵の GBV-C型，HGV型、アジア型に一致した.【考案】我々はアジア アフリカ・オーストラリアにおけるGBV-C/HGVのgenotypeとその分 布を模討した. 各国でのGBV-C/HGVは分子系㧧椡で，3つの

genotype, すなわちアフリカに多いGBV-C型、アメリカに多いHGV 型およひ、アジアに多いアジア型に分類可能であった。またRFLP法

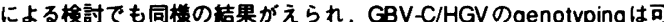
能であると考えられた．今後genotype間における監床的意䄰につき 模討予定である。

索引用語：GBV-C/HGV，分子系統解析
P 183 当科の血没・悪性䏸俱疾患症例についてのHGV感染調查 鳥取大学医学部小児科

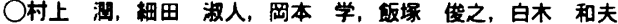

察引用語 1 . HGV

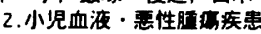

【目的】G型肝炎ウイルス(HGV)は频回合血例で佁出率が品い。当科

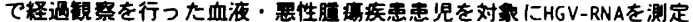
し、隔性者の堛床経過の湌时を行った。

【対象・方法】対象は，1985年11月〜 1996年4月に当科を受暗した血

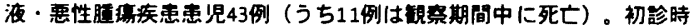

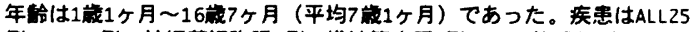

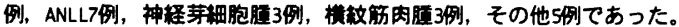
HGV-RNAは, 血清 $100 \mu$ lをAGPC法て抽出し，5'-UTRにprimerを設計し たnested RT-PCR法で怡出した。

【結果】対象43例のうちHBs抗原陑性例は2例(4.7\%)，第2世代HCV抗体 陽性例は14例 (32.6\%)，HCV-RNA陽性例は8例(18.6\%)であった。 HGVRNA恸性例は6例 (14.0\%)であり, いずれもHBs抗原, HCV-RNAは陰性で あった。症例1は87年発症のANLL。HGV-RNAは粭血前には隍性だったが

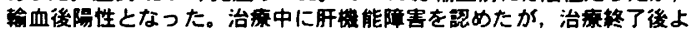
り正常化した。症例2187年発症のANLL。治英終了後, 肝機能障害加 約3ヶ月间䌇いた後正常化した。症例3は90年発症のALL。治病中には 肝機能障害を琶めたが，宽解中は正常であった。94年1月に原病のた め死亡した。症例4は93年発症のALL。HGV-RNAは輪血前には院性だっ

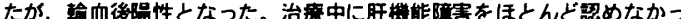
た。94年7月に原病のため死亡した。症例51933年発症のALL。HGV-RNA

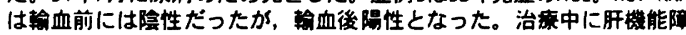
害を記めたが，治拣昸了後より正常化した。症例6195年発症のNHL。 HGV-RNAは輸血前には哣性だったか，血後陽性となった。治瘄中，

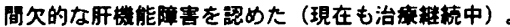

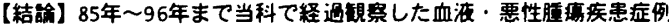
におけるHGV-RNA淂性率は14.exであった。HGV陽性者はHBC抗体やHCV 抗体による供血者スクリーニンク瞰台後の输血例でもみつかっており， 現行の献血スクリーニングではHGVを排賖てきないと考えられた。

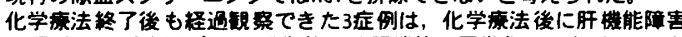
が遗延した1症例を含め，長期的には肝機能は正常化しており，HGW 持続的に訮機能障害を起こす可能性は低いと考えられた。

P 184 アルコール多飲者におけるGBV-C/HGV感染の臨床的検討 名古屋市立大学第 1 内科

○祖父江聡，東克謙，中尾春寿，水野弥一，高橋佳阔，佐宗克久， 埜村智之，伊碀誠

【目的】アルコール多钦者においてHCV感染例が高率に存在し，肝病 変の進展に影整を及ほす可能性が示唆されている。しかし、 GBV-C/ HGV (以下HGVのアルコール多飲者との関連はまだ明かではない，今 回我々は、アルコール多飲者におけるHGVの感染状況および肝障害へ の関与についてHCVと比較検討した。

【対象および方法】 HBsAg陰性であり哈血歷, 刺青、針治瘖歷がなく 組䋐誩断をし得だアルコールと肝研究理診断基準・における常習飲酒 家22例および大酒家31例の53例を対象とした．方法は，HGVのhelicaselike coding regionでRT-nested PCR法にて検出し、陽性例はPCR product をABI 営光autoread sequencerにて sequenceした

【結果】アルコール多飲者53例のうちHGV-RNA陽性者は15例(28.3\%)

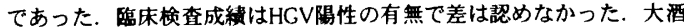
家および常習飲酒家におけるHGV-RNA陽性率は各々 $31.8 \%$ ，25.8\%と 有意差を認めず，アルコール㧒取最との関連は認めなかった，HCV陽 性者44例中13例 (29.5\%)にHGV-RNAを認め, HGV-RNA 陽性例では15 例中13例 (87\%)がHCV隄性でありHCVとHGVの重感染例が多かった。 またHGV-RNA単独晹性例は2例のみでありその組織像はhepatic fibrosis とacute hepatitisであった。肝組織像がアルコールの影謷を認めない慢 性肝炎であったHCV-Ab陰性例2例は，ともにHGV-RNAは陰性であっ た。肝稳合併例では11例中2例がHGV-RNA陽性であったが、全例で HCV-Abが陽性であった. またHGV-RNA晹性例での核酸のhomologyは 81\%-90\%でありアミノ酸のhomologyは96\%-100\%であった

【結語】アルコール多飲者におけるHGV-RNA陽性頌度はHCVより低 く，多くの症例はHCV との重感染であり，感染経路が同様である可能 性が示焧された。またHCV単独ではアルコールやHCVほどの肝組織へ の影要は認めなかった。

索引用珸 1.アルコール 2. HGV 
P 185 慢性肝疾患患者、血液透析患者および commercial sex workerにおけろ G 型旰炎ウィルスの感染

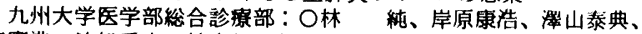

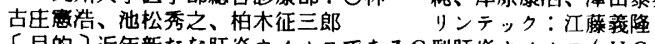
[目的]近年新たな盰炎ウィルスである G 型肝炎ウィルス( HGV)

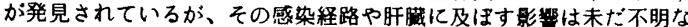
点が多い。これらの点を解决するためC 型慢性䀒宛患患者、H C Vの 感染率が高い血液透析患者および commercial sex worker (CSW) のH G V R N A を利定し、検討したので報告する。

[対象および方法] C型慢性肝疾患患者 247 洌、血液透析患者 494

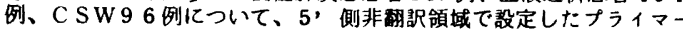
を用いたP C R 法にてHGVRNA を测定した。その他、HCVRNA ( P C R 法)、HBs 抗原 (RPHA法)、HB c 抗体 ( R I A 法)

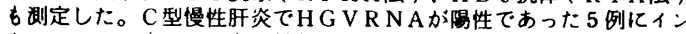
ターフェロン（IF N)加投与されていた。

〔成縝了 C 型慢性肝疾患でのH G V 感染は全体で 22 例、8.9\%で、 慢性非活動性肝炎 $7.7 \%$ 、慢性活性肝炎 $10.6 \%$ 、肝硬変 $7.7 \%$ 、 肝癌 $8.2 \%$ て病型による差はみられなかった。 H G V感杂例の输血歴 は $45.5 \%$ であった。I F Nが有効であったC型慢性肝炎患者 2例中 1 列に I F NによるH G V R N A 持続陵性化と肝機能の正常化が られたか、無効であった 3 例中 2 例では持続陰性化がみられたか、䀒 機能の正常化はみられなかった。透析患者でのHGV 感染は全体で 34 例、6.9\%で、透析期間が 10 年以上では $12.6 \%$ と 9 年以下の 4.4 \%に比較して有意に高率であった $(\mathrm{p}<0.01)$ 。 H G V感染例の翰 血歴は $64.7 \%$ であったが、透析経過中に输血歴もなく H G Vに感染 し、キャリア化した例もみられた。また、透析患者における肝機能異 常例はH G V 単独感染 133 例にはなく、H C V 重襩感染 21 例中 19.0 \%であった。C SWにおけるH G V感染は全体で 12 例、1 $12.5 \%$ で、 就業年数が 5 年以上では $24.3 \%$ と 4 年以下の $3.6 \%$ に比㜞し有意に 高率であった $(\mathrm{p}<0.01)$ 。年龄やH C V、H B Vおよび梅㶳など の感染とは関連がかった。

[結論] H G VはH C V との重複感染もみられ、H C V と類似した感 染様式が考えられたか、肝障害との関連は否定的であった。また、H G Vは I F Nによろ排除も可能であるが、その感受性はH C V とは異 なっているてとが考えられた。

索引用語: 1. G 型肝炎ウイルス 2 . 疫学

\section{P 186 夫如间染染が疑われた急性G型肝炎の解析}

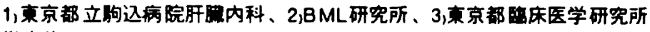

微生物

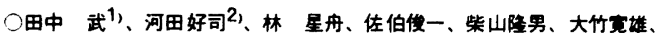
田中 ${ }^{1}$ 、竹内朋子、小原迹法

近年、Simonsらにより分略されたG型旰炎ウイルス(HGBV-C)の監床

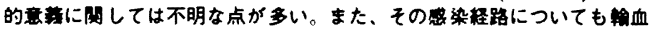
以外の释路は不明である。今回、我々は非A、非B、非C型急性肝炎例

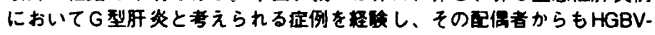

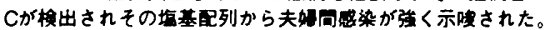

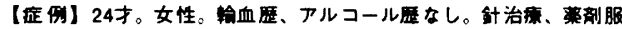
用歷なし。平成 8 年 5 月中旬頃より心窟部不快感出现。眼球結骐の黄染 を指据され 5 月29日外来受塔。AST 1212IU/L、ALT734IU/L、総ビリル ビン9.2mg/dl、ALP 443IU/L、yGTP 252IU/L、ブロトロンビン時同100 $\%$ HA Ab (-), IgMHA Ab (-), HBS Ag (-), HBS Ab (-), IgM HBC Ab (-), HCV Ab (第 2 世代)(-)、HCV RNA (-)。HGBV-C RNA(+)。経週はALT。

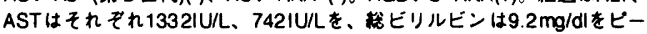
クに一性の肝害を呈し、吐症12 迥挠にはALT、ASTは正常化、黄值 の消失を見た。释過中 HGBV-C RNA閶性が持統、トランスァミナー せ正常化後もHGBV-C RNAは陆性でありキャリアー化が考えられた。本

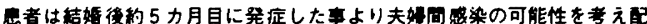
信者についてもHGBV-Cの检来をしたところHGBV-C ANAが检出され、

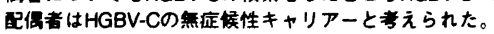

(HGBV-C RNA $の$ 出とdirect sequence) HGBV-CisSimons. Yoshibaらにより報告されたNS 3 regionをブライマーとしたPCR法によ

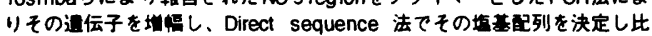

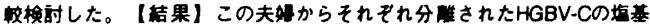
列はNS3领城では完全に一致したが、Simons、Yoshibaらの報告した HGBV-Cとは 4 力所で㙁基配列が暴なっていた。

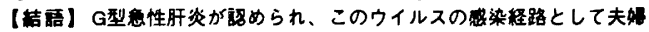
同策染の可能住が強く示喛された。

来引用铻 1. G 型急性肝炎 2. 夫圽间蝺染
P 187 小児の肝疾患におけるG型肝炎ウイルスの間与

大阪大学医学部小児科、神声大学医学部微生物学教室"

○多田香苗、田尻 代、澤田 敦、古座岩宏韩、意谷ゆり、堀田

[目的] C 型肝炎ウイルス関連検查の進歩により小児の非 $\mathrm{A}$ 非 $\mathrm{B}$ 旰 疾患の過半数はHCV 感染によることが明らかとなった。しかしなお 小児期の急性肝障害や慢性所疾患の一部の症例は原因不明である。 G 型肝炎ウイルス (HGV) は 1995 年 Simmond らによって報告され た新しいヒト肝炎ウイルスである。血液を介して感架し、急性肝炎、 慢性所炎を発症するといわれているが、恨性肝炎の非峆血例におい てもHGV陵性者が報告されており、感染経路、自然経過の解明が照 題となっている。今回、小児の非 B韭C厈炎、およびHCV 感染㤡に ついて HGV 感染の関与を梭封した。

[方法] 小児の非 B 非 C㬳炎 29 例，C 型肝炎 29 例の計 58 例について 血清から抽出したRNAよりランタムプライマーを用いて CDNAを作 䌘し、NS3 領域に 2 組のプライマーを設定した nested RT-PCR 法によ る血清 HGV-RNA の検查を行った。 first PCR, nested PCR 反応之も、 $94^{\circ} \mathrm{C} 1$ 分、 $40^{\circ} \mathrm{C} 1.5$ 分、 $72^{\circ} \mathrm{C} 2$ 分を 1 サイクルとして 35 サイクルず つ行ない、agarose gel 電気泳動, ethidum bromide染色により增幅さ れた nested PCR 産物 ( $83 \mathrm{bp}$ ) の㭲出を行った。

[成綨] 小児の非B非C肝炎の 29 例の中で、1 例が HGV-RNA淂性 であった。この症例は、急性りンパ性白血病のため 15 葴時より化

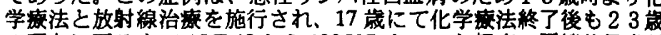
の現在に至るまでALT 40 から $100 \mathrm{U} / \mathrm{L}$ といつた軽度の肝機能異常か 持続している症例である。HCV 感染例については、29 例中 5 例て

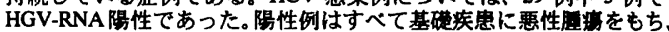
頻回の䑶血を受けていた症例であった。また、C 型肝炎においてサ フタイプの重複感染を見た 2 例中 1 例において HGV-RNA 陽性であ つた。

[結論] 小児の非 B非 C 旰炎 29 例中 1 例 (3.4\%)、HCV 感染 29 例中 5 例 (17.2\%) で HGV-RNA陽性であった。HGV 単独感染の1例におい ては、肝炎は軽度であると思われた。本邦において一般健常者のHGV 感架率は約 $1 \%$ と報告されており、HGV抗体系のスクリーニング法 が未だ開発されていない現段陼では、渝血による HGV 感染は叱生し 続けるものと予想される。今後、小児におけるG型肝炎ウイルス感 染の臨床像を明らかにすることが必要であると考えられた。 索引用語 $1 . G$ 型肝炎 2. 輸血

\section{P 188 非A 非B，非C型各程肝疾急におけるGBV-Cの湌出} 佐贫医科大学内科

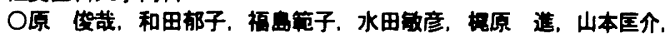
㙁

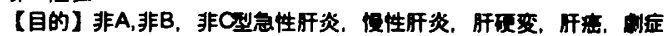
肝炎应例についてGBV-Cの間与について梌討した。

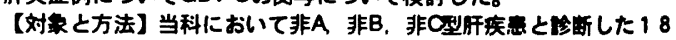

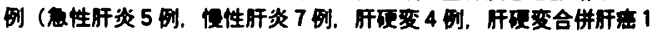

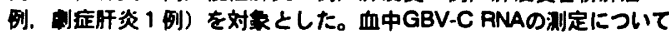
は. $5^{\prime}$ noncoding region (5NC) をprimerに用い Nested PCR法 にて模出した。(Abbott)

【结果】18 例中 3 例に血中GBV-C RNAが模出された。内比は，

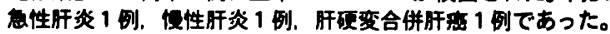

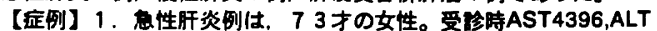

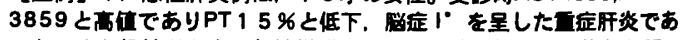

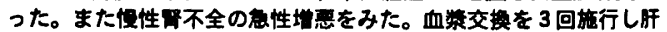

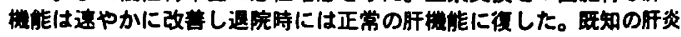
virus marker(HBsAb, HBcAb, HAAb, HCVAb, HCVRNA) また, 他の virus marker(CMV,HZV, EBV, Coxsackie, Infulensae, Mumps $\Phi$ IgM抗体) は全て性。内服集のDLST, 自己抗体(ANA,AMA)も隌

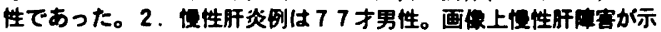

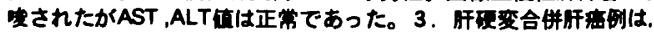

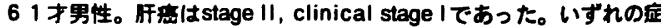

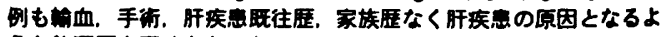
うな政酒展も蚂めなかった。

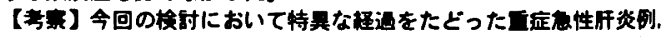

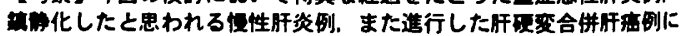
おいてGBV-C RNAか模出された。GBV-Cは，抗体系による珍断は 現在不可能であるが，5NC をprimer としたPCR法によるより碃实な

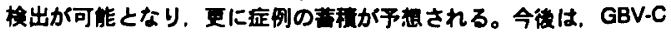
RNA genotypeの舴析による分子度学的研究が严異である。

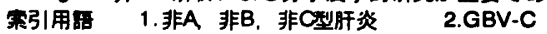

